\title{
Introduction of Head Start and Maternal Labor Supply: Evidence from a Regression Discontinuity Design
}

\author{
by \\ Cuiping Long* \\ University of Illinois
}

\begin{abstract}
CES 16-35
July, 2016

The research program of the Center for Economic Studies (CES) produces a wide range of economic analyses to improve the statistical programs of the U.S. Census Bureau. Many of these analyses take the form of CES research papers. The papers have not undergone the review accorded Census Bureau publications and no endorsement should be inferred. Any opinions and conclusions expressed herein are those of the author(s) and do not necessarily represent the views of the U.S. Census Bureau. All results have been reviewed to ensure that no confidential information is disclosed. Republication in whole or part must be cleared with the authors.

To obtain information about the series, see www.census.gov/ces or contact J. David Brown, Editor, Discussion Papers, U.S. Census Bureau, Center for Economic Studies 5K034A, 4600 Silver Hill Road, Washington, DC 20233, CES.Papers.List@census.gov. To subscribe to the series, please click here.
\end{abstract}




\begin{abstract}
I use the non-public decennial censuses in 1970 to investigate the effect of the Head Start program on maternal labor supply and schooling in its early years. I exploit a discontinuity in county-level Head Start funding beginning in the late 1960s to explore differences in countylevel maternal employment and maternal schooling. The results provide suggestive evidence that the more availability of Head Start led to an increase the nursery school enrollment of children and a decrease in maternal labor supply. In addition, the ITT estimates imply a relatively large, negative effect of enrollment on maternal labor supply. However, the estimates are somewhat sensitive to addition of covariates and the standard errors are also large to draw firm inferences.
\end{abstract}

${ }^{*}$ Cuiping Long, Department of Economics, University of Illinois at Chicago, 601 South Morgan UH718 M/C144 Chicago, IL 60607, USA. E-mail Address: clong22@uic.edu. I am especially indebted to Robert Kaestner for many helpful discussions. I also thank Marcus Casey, Ben Feigenberg, Rachel Gordon, Darren Lubotsky, Ben Ost, Steven Rivkin, Jeffrey Schiman, Javaeria Qureshi, and seminar participants at UIC for providing helpful comments. I thank Douglas Miller and Jens Ludwig for data on Head Start spending and the Chicago Census RDC for providing access to the restricted-use census files.Disclaimer: Any opinions and conclusions expressed herein are mine and do not necessarily represent the views of the U.S. Census Bureau. All results have been reviewed to ensure that no confidential information is disclosed. 


\section{Introduction}

Head Start is an early child development program that provides free child care for eligible low-income families. Started in the summer of 1965, the program was part of the War on Poverty initiative to break the poverty cycle by preparing disadvantaged children for school. As a leading effort in preschool education, Head Start drew heated political and academic attention on its effectiveness to improve children's school readiness (Vinovskis 2005). While the effect of Head Start on children's school readiness deserves attention, Head Start may also affect mothers' labor supply decisions and family consumption, a potential direct influence on low-income families' economic well-being, poverty, and children's well-being (Long 2015). These questions on the impact of Head Start on mothers' employment are particularly interesting in the 1970s and 1980s, which was a period of relatively low-levels of maternal labor force participation, and the most recent period when mothers are much more likely to enter the labor market.

In this paper I investigate the effect of Head Start on maternal labor supply during the early years of the program with a regression discontinuity research design. In particular, I exploit a discontinuity in Head Start funding (grant writing assistance) across counties originating in 1965 that resulted in an increase in Head Start availability/enrollment in these counties in late 1960s to identify the impact of Head Start introduction on maternal labor supply, earnings, welfare participation, and maternal schooling in 1970. Ludwig and Miller (2007) used the same identifying variation to examine the effect of Head Start on child health outcomes (e.g. mortality) and their education attainment at adulthood. The contribution of this study is to provide the first evidence on the effect of Head Start on pre-school enrollment and family economic decisions in 1970 as a result of Head Start. These outcomes are partially the precursors of later outcomes studied by Ludwig and Miller (2007).

I find some suggestive evidence that more availability of Head Start led to an increase in nursery school enrollment of three- and four-years old, a decrease in maternal labor supply including probability of current employment, hours of work, probability worked last year, number 
of weeks worked last year, and earnings, and an increase in receipt of public assistance and school enrollment.

Specially, I find that Head Start funds per four-year old increased by approximately $\$ 130$ (a nearly 100\% increase off the control group mean) as a result of the grant-writing assistance though this increase is insignificant in most specifications. The standard errors are large due to the noisy take-up of the assistance and possibly the actual grant application. Interestingly, nursery school enrollment for three and four years old in 1970 increased significantly by approximately two percentage points for treated counties (an approximately $71 \%$ increase off the control mean) near the threshold for extra assistance. ${ }^{1}$ This increase is smaller than and consistent with the magnitude of the increase in Head Start funds per four-year old. Specifically, the average cost per child in full-year Head start was approximately \$1056 in 1970 ("Project Head Start Statistical Fact Sheet: Fiscal Year 1970”), this means that an increase of $\$ 130$ per four-year old in Head Start funding may increase nursery school enrollment for three- and four-year olds by up to 6.1 percentage points assuming equal number of three- and four-year olds and perfect take-up in enrollment.

Overall, the ITT estimates imply relatively large, negative effect of Head Start enrollment on maternal labor supply though most are insignificant. For example, I find that the Head Start grant-writing assistance reduced the probability of current employment by nearly 2.5 percentage points (roughly $7.5 \%$ off the control group mean), a decrease that is approximately the same magnitude of the increase in nursery school enrollment. In addition, there is also some suggestive evidence that the greater availability of Head Start increased the school enrollment for younger mothers. The standard errors are also quite large, making it difficult to rule out large effects.

\footnotetext{
${ }^{1}$ Head Start enrollment was not reported separately in the 1970 and 1980 decennial censuses.
} 


\section{Related Literature}

Long (2015) provides extended review on the related literature on the relationship between Head Start and maternal labor supply, and therefore I do not repeat such review here. Instead, I briefly summarize the main conclusions from the literature. As pointed out in Long (2015), there is limited evidence on the effect of Head Start on maternal labor supply (Hsueh and Farrell 2012 and Sabol and Chase-Lansdale 2015). In addition, studies that focused on different child care settings generally find mixed results of child care on maternal employment (Fitzpatrick 2010; Cascio 2009; Gelbach 2002; Baker, Gruber, and Milligan 2008; and Havnes and Mogstad 2011), providing little insight for the effect of Head Start on maternal labor supply. An extensive review of studies on child care expenditures and maternal labor supply by Blau and Currie (2006) also suggests a wide array of estimates though they conclude that most reliable studies generally find small labor supply elasticities (Long 2015).

A recent study by Long (2015) that used experimental data from the early 2000s showed that the availability of Head Start had little effect on the probability of employment, income, and welfare participation of mothers though it increased full-time employment and maternal course enrollment modestly for some mothers. However, it is unclear how Head Start may have affected maternal labor supply in the 1970s. In particular, the mothers most likely affected at that time may differ significantly than in the more recent period. For example, studies in the U.S. that use data from the pre-1990 period generally find larger labor supply responses than studies that use data from post-1990 (Gelbach 2002; Cascio 2009; and Fitzpatrick 2010) though these studies focus on child care settings quite different from Head Start both in terms of the population of mothers served and the age of their children. ${ }^{2}$ To summarize, the current literature lends little evidence on the effect of Head Start on maternal labor supply in its early years.

\footnotetext{
${ }^{2}$ Sabol and Chase-Lansdale (2015) used the same data with those in Long (2015) and examined the effect of Head Start on parents' education advancement and transition from unemployment to
} 


\section{Conceptual Framework}

In a simple theoretical framework (Long, 2015), a mother is concerned not only with her own consumption and leisure, but also with child development. Child development is produced from maternal time and purchased child care. The mother divides her time between work, home production time (maternal time), and leisure. As the price of child care decreases due to a child care subsidy, both the substitution effect and the scale effect of the child development production function suggests that the use of market child care will increase. Maternal care will decrease if the substitution effect dominates. At the same time, the tradeoff between consumption, leisure, and child development in the utility function also suggests both a substitution effect and income effect when the price of child care decreases. Specifically, the substitution effect suggests that consumption and leisure decreases while the income effect suggests the opposite. All together, the net effect on the amount of work and probability of employment is ambiguous (Long, 2015).

\section{Research Design}

I exploit the discontinuity in Head Start funding across counties in the late 1960s to identify the impact of Head Start on maternal labor supply and schooling in 1970 with a regression discontinuity design. In 1965, the Office of Economic Opportunities (OEO) helped the 300 poorest counties to apply for Head Start funds (Ludwig and Miller 2007). ${ }^{3}$ The OEO help resulted in a discontinuity in Head Start funding for counties right around the poverty threshold (i.e. 59.1984 percentage points) the OEO used to define the poorest 300 counties.

The identifying assumption for the regression discontinuity design is that the county-level maternal employment outcome is continuous in the county poverty rate and other observed and

employment. They find that some positive effect on education advancement and no effect on the transition.

${ }^{3}$ Vinovskis (2005) also documented that OEO contacted the 300 poorest counties about the funding opportunities of Head Start though the author did not elaborate on this matter. 
unobserved county-level characteristics. This underlying assumption would be violated if counties were able to precisely manipulate their 1960 poverty rates to be above the poverty threshold used by the OEO in order to secure Head Start funds. However, since the county poverty rates used by the OEO are based on a 1964 re-analysis of the 1960 census, it is unlikely that counties had ability to precisely manipulate on which side of the poverty threshold they fall (Ludwig and Miller 2007).

Because the OEO's grant-writing assistance is a deterministic function of 1960 county poverty rate, i.e., only counties with 1960 poverty rate above 59.1984 received the assistance, I use a sharp regression discontinuity design. Under the assumption that county-level maternal labor supply and schooling outcomes are smooth functions of 1960 poverty rate, I estimate the intent-to-treat (ITT) effect of the OEO grant-writing assistance $\theta$ using the following quadratic polynomial and local linear regressions.

The quadratic polynomial regression equation is

$$
\begin{gathered}
Y_{c}=\alpha+\beta_{1}\left(P 60_{c}-P\right)+\beta_{2}\left(P 60_{c}-P\right)^{2}+\theta T_{c}+\beta_{3}\left(P 60_{c}-P\right) T_{c} \\
+\beta_{4}\left(P 60_{c}-P\right)^{2} T_{c}+v_{c}
\end{gathered}
$$

and the local linear regression equation is

$$
Y_{c}=b+\rho_{1}\left(P 60_{c}-P\right)+\theta T_{c}+\rho_{2}\left(P 60_{c}-P\right) T_{c}+\varepsilon_{c}
$$

and

$$
T_{c}=1\left[P 60_{c} \geq 59.1984\right]
$$

where $T_{c}$ (i.e. treatment) is a deterministic function of 1960 county poverty rate and equals one for counties with poverty rate above the poverty threshold $P=59.1984 . Y_{C}$ represent the countylevel maternal labor supply and schooling outcomes (e.g. fraction employed and average hours of work) for county $c . P 60_{c}$ is the 1960 county poverty rate for county $c . P$ is the poverty rate cutoff 
for grant-writing assistance and $P=59.1984 . v_{c}$ and $\varepsilon_{c}$ are the error terms. I allow 1960 county poverty rate to have a flexible relationship on both sides of the poverty cutoff. $\theta$ captures any discontinuity in the county-level maternal labor supply and schooling outcomes that arises from the discontinuity in the grant-writing assistance and identifies the ITT effect of the assistance. ${ }^{4}$

In practice, I also compare the overall fit to the data of the cubic and quartic polynomial regressions and the property of their approximation of the limit (equation (1)) around of the cutoff. While the higher orders polynomials provide as similar or better overall fit compared to the quadratic model, they offer visually poorer approximation to the limit at the cutoff, particularly for the odd-ordered polynomials. Moreover, Gelman and Imbens (2014) show that polynomial regressions with orders higher than quadratic are less desirable as they may increase the chance of type I error and the underlying weights associated with the regressions also tend to be noisy, for example, they can fluctuate substantially around the poverty cutoff.

To improve precision, I include in some regressions county-level characteristics for $18-50$ years old mothers with children aged three to four and the squared term of the characteristics. These variables include fraction single mother, years of schooling, age (in years), number of children under 18, fraction white, and fraction black. Similarly, I also include county population characteristics including fraction urban residents, fraction aged 18 to 24 , fraction aged 25 to 34 , fraction aged 35 to 54 , and fraction aged 55 and older.

\section{Estimation Sample}

Due to small sample size near the cutoff and to improve precision, I estimate equations (1) and (2) with observations away from the cutoff. However, the approximation at the

\footnotetext{
${ }^{4}$ I report cluster-bootstrap standard errors. Standard errors are clustered by state to account for residual correlation of the dependent variables among counties within the same state. Bootstrap (500 times) is used to adjust for the small number of clusters (Cameron and Miller 2015). For example, there are 22 clusters in the data when the estimation sample includes counties within ten percentage points to the right of the poverty threshold and ten percentage points to the left of the poverty threshold.
} 
boundaries can be potentially sensitive to the size of the poverty range over which equations (1) and (2) are estimated. The main poverty ranges I use to estimate both equations are within five and ten percentage points to the left of the cutoff and within five and ten percentage points to the right of the cutoff. These poverty ranges are small enough to stay local to the poverty cutoff but also include large number of counties with similar 1960 poverty rates around the cutoff.

To gauge a reasonable poverty range, I also estimate equations (1) and (2) with bin dummy variables included as additional regressors for various poverty ranges (Lee and Lemieux, 2010). ${ }^{5}$ Each bin dummy variable represents counties within a two-percentage point bin of the 1960 poverty rate. For example, there are 18 bin dummy variables on either side of the cutoff within a 36-percentage point poverty range. I report in Table A1 the p-values from Wald tests on the joint significance of the bin dummy variables. As shown, these dummy variables are mostly jointly significant when the poverty range is above 15 percentage points, suggesting that these poverty ranges may be too large either due to potential discontinuities away from the poverty cutoff or that the models provide poor fit on such a large range of data (Lee and Lemieux 2010). The bin dummy variables become mostly insignificant at poverty range 10 and below, however, it is possible that the smaller sample sizes increased standard errors.

\section{Data}

The data include the long-form restricted-use decennial censuses from 1970 and 1980 and the Head Start federal expenditures in 1968 and 1972 by county and the 1960 county poverty rates used by Ludwig and Miller (2007). I also collected county-level data from the 1960 census tabulations to conduct falsification analyses, which examine whether counties on either side of the grant writing assistance threshold differed in 1960.

\footnotetext{
${ }^{5}$ In estimation, I omit two of the bin dummy variables, one on either side of the poverty cutoff, to avoid perfect collinearity with the treatment variable $T_{c}$.
} 
The long-form, restricted-use decennial censuses survey individuals from on average every one out of six households in the United States with questions on individuals' demographic characteristics (e.g. age, race, marital status), education, and employment among others. The data include variables describing each person's relationship to the head of a household and their ages. I use these variables to limit the sample to mothers aged 18 to 50 years old with children aged 3 to 4 years old (i.e. Head Start aged children). ${ }^{6}$ I drop mothers who were in military or in jail. I generate an indicator variable for whether a three- or four-year old was currently enrolled in nursery school, i.e., grade currently attending is nursery school. ${ }^{7}$ The maternal labor supply outcomes are coded from questions on a person's current/last year's employment status, hours of work (reference week), number of weeks worked last year, earnings, and welfare assistance status. Individuals are coded as receiving welfare assistance if she reported receiving a positive number of public assistance cash. In addition, individuals reported if they were currently enrolled in school and I use this variable to generate an indicator variable for current school enrollment.

The individual data are aggregated to the county-level (sampling weights are used) and the analysis sample consists of county aggregates for 18-50 years old mothers with children aged 3 to 4 years old (e.g. proportion currently employed by county). Before aggregation I dropped counties with less than five households to improve precision of the county-level aggregates. The county aggregate of nursery school enrollment is calculated as the fraction of three and four-year olds currently attending nursery school. In addition, county-level covariates include measures of the fraction of different age groups (e.g. 18-24, 25-34, 35-54, 55+), characteristics for mothers in my sample include percent single mothers, number of children, years of schooling, race compositions (i.e. percent White and percent Black), and age (in years).

\footnotetext{
${ }^{6}$ To identify all mothers affected by Head Start, I limit the sample to mothers with children aged three to four. In addition, mothers aged 40-50 with children aged three to four accounted for around $9-10 \%$ of the sample. I include these mothers to increase the cell size in small counties.

${ }^{7}$ In 1980, respondents were instructed to report nursery school if they were unclear whether a Head Start program is for nursery school or kindergarten (see codebook in IPUMS USA). No such instructions were given in 1970, though Head Start is counted as regular school in 1970 and individuals were instructed to report regular school attendance.
} 
The "running" variable for the regression discontinuity analysis is the 1960 poverty rate. The main independent variable of interest is an indicator variable for whether the 1960 poverty rate in the mother's county of residence was above the poverty threshold (threshold $=59.1984 \%$ ) used by OEO to offer grant writing assistance. The data on federal expenditures include countylevel Head Start funding per 4-year old in 1968 and 1972 and other county-level social spending. These data provide me with evidence on the discontinuity in Head Start funds that mirrors the discontinuity in the provision of grant-writing assistance. They were merged to the county-level data from decennial censuses.

For the falsification analyses that test whether pre-policy county-level outcomes and characteristics differed for counties around the OEO poverty threshold, I collected data on county-level characteristics from 1960 public census tabulations. Unlike the restricted-use individual level data, the public census tabulations give less flexibility to construct variables, for example, restricting the age of the children. The characteristics I obtained from the public tabulations include labor force participation rates for women with children under 6 and for married women with children under 6 , unemployment rate, median family income, median years of school for population aged 25 and over, and fraction enrolled in school for population aged 25 to 34 years old.

\section{Results}

\subsection{Effect of Grant-writing Assistance on Head Start Funding per Four-year Old}

In Panel A of Figure 1 I present the county-level Head Start funding per four-year old in 1968 by 1960 county poverty rate, centered at the poverty cutoff. Each data point is a county. The Head Start funds per four-year old were on average higher for counties that received the grantwriting assistance (i.e. those with positive poverty rate relative to the cutoff). Specifically, the average fund per four-year old was $\$ 130$ for control counties within five percentage points left of the poverty cutoff but $\$ 290$ for treated counties within five percentage points right of the poverty 
cutoff. However, about $62 \%$ of counties within 10 percentage points to the right of the cutoff had zero Head Start funds, suggesting that many counties may not have taken up the grant-writing assistance or the subsequent actual application. This renders the estimates on Head Start funds rather noisy.

In Panel B I present the same data but grouped by two-percentage-point bins and the predicted values from regressions using county-level data. ${ }^{8}$ Each data point is the average county Head Start funds per four-year old for counties within a two-percentage point bin. The dotted line is the predicted values from a quadratic polynomial regression (equation (1)) and the solid line is the predicted values from a local linear regression (equation (2)). The figure suggests an approximately \$130 jump in 1968 Head Start funds (nearly 100\% increase off the control group mean) at the poverty cutoff.

In the same fashion, in Figure 2 I report the Head Start funding per four-year old in 1972. The average fund per four-year old was $\$ 159$ for control counties within five percentage points left of the poverty cutoff but $\$ 334$ for treated counties within five percentage points right of the poverty cutoff. However, Panel B shows that the discontinuity (approximately \$76) in Head Start funds at the cutoff was no longer as apparent as in 1968.

In Table 1, I report the estimates on the effect of the grant-writing assistance on Head Start funds per four-year old. For 1968, the estimates from quadratic polynomial regressions and local linear regressions are roughly similar and the estimates are not very sensitive to the range of data used. Overall, the estimate suggests an approximately 100\% increase in Head Start fund per four-year old in the treated counties compared to the control counties (i.e., an $\$ 132$ increase off

\footnotetext{
${ }^{8}$ Bin size selection: To select appropriate bin size, I use goodness-of-fit approach suggested by Lee and Lemieux (2010) to identify an ideal bin size when plotting the figures. In particular, I use bin sizes of $0.25 \mathrm{pp}, 0.5 \mathrm{pp}, 1 \mathrm{pp}$, and $2 \mathrm{pp}$ and created bin dummy variables for each bin size. I then run a linear regression of proportion currently employed on the bin dummy variables and compare the overall fit of the model. For example, I compare the model fit when $2 \mathrm{pp}$ bin size was used (restricted model) to when $1 \mathrm{pp}$ (unrestricted model) was used. The tests reveal no significant difference in the model fit among the different bin sizes. In fact, the p-values for the goodness-of-fit tests are almost all above 0.5 and mostly above 0.9 . I then choose the $2 \mathrm{pp}$ as my bin size to allow for sufficiently large number of counties in each bin.
} 
the control group mean $\$ 130$ ). Despite the large discontinuity, estimates are statistically insignificant.

\subsection{Effect of Grant-writing Assistance on children's nursery school enrollment}

Figure 3 shows the nursery school enrollment rate for three- and four-year olds. I report both the actual data points from binned data and the fitted values from quadratic polynomial and local linear regressions. Panel A reports the fraction enrolled in nursery school for all three- and four-year olds. The nursery school enrollment was two percentage points higher (a $71 \%$ increase) for treated counties (i.e. received the grant-writing assistance) than control counties (i.e. did not receive such assistance) at the poverty threshold. Panel B reports the fraction enrolled in nursery school for three- and four-year olds who live in families with below county median income. Interestingly, the nursery school enrollment rates are similar between poorer households and all households considering that Head Start targets mainly low-income households. However, it is possible that most families in these counties qualify for Head Start because these are very poor counties and it is also possible that the take-up/awareness of Head Start is lower among poorer households.

In Table 1, I report the regression estimates of the effect of the grant-writing assistance on nursery school enrollment for three- and four-year olds. As a result of the assistance, the nursery school enrollment increased by approximately two percentage points, a $71.4 \%$ increase off the control group mean. Similarly, the nursery school enrollment increased by $80 \%$ (two percentage points increase off control group mean of 0.025 ) for counties near the OEO threshold who were offered the grant-writing assistance.

Compared to the increase in enrollment (nearly an increase of 20 percentage points) in Ludwig and Miller (2007), the increase in enrollment is much smaller in this study. However, Ludwig and Miller (2007) used enrollment data based on nationally representative sample. The nursery school enrollment (therefore Head Start enrollment) is much lower in my sample of 
counties. To examine the accuracy of this measure, I calculate the fraction of three- and fouryears old enrolled in nursery school by county poverty rate and for the whole nation (Table A2). In general, the nursery school enrollment decreases substantially as counties become poorer. For example, nearly $12 \%$ were enrolled in nursery school for the 2026 counties with poverty rate below $39.1984 \%$ while only $4 \%$ were enrolled in nursery school for the 296 poorest counties in the country. The national average enrollment is approximately $11 \%$, which is consistent with other sources (National Center for Education Statistics) and similar to the enrollment in the 2026 less poor counties. ${ }^{9}$ In 1980 , the nursery school enrollment increased dramatically for all counties. For example, the national average is now $28 \%$, again consistent with other sources (National Center for Education Statistics), while the enrollment in the poorest counties increased to $16 \%$.

One question that follows is whether a two-percentage point increase in nursery school enrollment is consistent with the increase in Head Start funds. The average cost per child in fullyear Head start was approximately \$1056 in 1970 ("Project Head Start Statistical Fact Sheet: Fiscal Year 1970"), this means that an increase of \$130 per four-year old in Head Start funding may increase nursery school enrollment for three- and four-year olds by up to 6.1 percentage points assuming equal number of three- and four-year olds and perfect take-up in enrollment. Therefore, a two-percentage point increase in nursery school enrollment seems to be reasonable.

\subsection{Are there discontinuities in other social spending?}

If other social policies also used the same poverty cutoff to determine program eligibility or funding, then the discontinuity in maternal outcomes might not be contributed to the mere effect of Head Start. To examine this possibility, in Table 1 I report the estimates of the effect of the writing assistance on other social spending. In 1968, counties to the right of the poverty cutoff

\footnotetext{
9 According to the "Digest of Education Statistics" published by National Center for Education Statistics (https://nces.ed.gov/programs/digest/d14/tables/dt14_202.10.asp), the national preschool enrollment rate for children aged three and four years is approximately $14 \%(14 \%=1003 / 7135)$ in 1970 and approximately 30\% (1889/6215) in 1980.
} 
(i.e., treated counties) received approximately $\$ 40$ more per capita (approximately $20 \%$ increase off the control group mean) in social spending than the control counties. There is no clear discontinuity in 1972. Though significant, the increase in other social spending in 1968 is much smaller than the increase in Head Start fund. Unfortunately I do not have insufficient information on the exact function of these other social spending. ${ }^{10}$

\subsection{McCrary Density Tests}

In Figure 4, I report the number of counties and the number of Households by 1960 poverty rate. The number of households (un-weighted) is the number of mothers with children aged three- and four-years old. As shown in Figure 4, there are no clear discontinuities in either the number of counties or the number of households around the poverty cutoff, suggesting that counties may not have precisely manipulate into treatment.

\subsection{Are there discontinuities in pre-policy measures of labor supply and schooling?}

To examine if counties near the threshold were similar pre-policy, I investigate whether there are discontinuities in the pre-policy measures of county labor supply and schooling at the poverty cutoff. Discontinuities in the pre-policy measures at the poverty cutoff may suggest potential manipulation into treatment. Table 2 shows the estimates of the effect of grant-writing assistance on 1960 county characteristics including labor force participation for women with children under age 6 , labor force participation for married women with children under 6 , county unemployment rate, median family income, median years of school for ages 25 and over, and fraction enrolled in school for ages 25 to 34 years. ${ }^{11}$ Overall, there are no significant

\footnotetext{
${ }^{10}$ According to Ludwig and Miller (2005), other social spending includes spending by " $H E W, H U D$, the US Department of Labor, and OEO, plus some selected programs run by the Department of Agriculture such as low-income housing programs and school lunches."

${ }^{11}$ These measures are collected from the public census tabulations of the 1960 decennial censuses and unfortunately they are not as finely defined as wanted.
} 
discontinuities in these measures. Additionally, in Figure A1, I provide the graphical evidence on these measures. Again, there are no clear discontinuities in these measures at the poverty cutoff.

\subsection{Are there discontinuities in the covariates?}

In Table 3, I report the p-values on the treatment variable from regressions in which the county-level covariates are used as the dependent variables. P-values of less than 0.05 mean that the treatment variable is significant at the $5 \%$ level or lower and therefore suggest a discontinuity in the covariate in question. Because many of these covariates are strongly correlated with each other (e.g., categorical variables), I also use a seemingly unrelated regression approach to test the joint significance of whether there is a discontinuity among all of the measured covariates. The pvalues obtained from separate regressions suggest that there are discontinuities in four of the twelve covariates, while the chi-squared tests from seemingly unrelated regressions suggest no statistically significant discontinuity among all covariates though the p-values from the chisquared tests are small.

\subsection{Estimates of the Effect of Head Start on Maternal Labor Supply and Schooling}

In Figure 5, I report fraction currently employed, mean hours of work, fraction worked last year, mean number of weeks worked last year, average earnings, proportion that received public assistance, and school enrollment by 1960 county poverty rate. I provide both the actual means for counties within two-percentage point bins and the regression fitted values from countylevel data (without controlling for covariates). Overall, Figure 5 identifies clear discontinuities in these measures. Specifically, mothers in counties that received grant-writing assistance are less likely to be employed, to work fewer hours and weeks, have lower earnings, and are more likely to receive public assistance and to be enrolled in school.

In Table 4 I report the estimates of the ITT effects of offering Head Start grant-writing assistance on maternal labor supply and school enrollment. I show estimates from regressions 
both without and with covariates included and from both polynomial regressions and local linear regressions. Covariates include all those listed in Table 3 and are included as quadratic terms. Columns (1) and (3) show estimates when covariates are not included and the estimates suggest that the availability of Head Start decreased maternal labor supply and earnings, but increased receipt of public assistance and school enrollment. For example, the probability of employment decreased by nearly five percentage points (approximately a 15\% decrease off the control group mean) as a result of the availability of Head Start. However, the estimates are roughly reduced by half and almost none are significant when the covariates are included in the regressions in columns (2) and (4). ${ }^{12}$ For example, the probability of employment decreased by 2.5 percentage points (a 7.5\% decrease off the control group mean) and the estimate is no longer significant. Nevertheless, the standard errors are quite large across all columns and this renders it difficult to rule out possible large effects. For instance, the 2.5 percentage decrease in the probability of employment (i.e., when covariates are included), though insignificant, is rather large considering that the nursery school enrollment increased only by 2 percentage points.

To summarize, estimates suggest rather large effects of Head Start enrollment on labor supply. The discontinuity in school enrollment was positive two percentage points, so the 2.5 percentage point decline in employment suggest that every mother whose child enrolled stopped working. Second, estimates are sensitive to the inclusion of the covariates suggesting that the quasi-experiment is less than perfect. Third, estimates are imprecisely estimated, which makes it difficult to draw firm inferences.

\section{Heterogeneity and Sensitivity Analyses}

\footnotetext{
12 Though mothers in counties to the right of poverty cutoff are more likely to be single and also have more children, fraction single and number of children, however, do not significantly alter the estimates on maternal labor supply and schooling when included in the regressions. Instead, counties' age composition seems to significantly alter the estimates when included in the regressions.
} 


\subsection{Heterogeneous Effects by Presence of Younger Children}

The labor supply response may differ among mothers by the presence of younger children at home due to differences in the budget constraints. To empirically test this, I estimate the effect of the availability of Head Start separately for mothers with younger children and for mothers with no younger children. The estimates are shown in Table 5. Overall, compared to mothers with younger children, mothers without younger children experienced larger increases in their children's nursery school enrollment (nearly $110 \%$ increase off the control group mean) but also larger decreases in probability of employment and hours of work. Again, the estimates are imprecisely estimated and it is difficult to conclude or to rule out large effects.

\subsection{Heterogeneous Effects on School Enrollment by Mother's Age}

The human capital model predicts that education investment will primarily occur early in life, because individuals face a longer horizon over which to reap the benefits of schooling (e.g. higher wages). Therefore, I expect to observe a larger response in school enrollment for younger mothers than for older mothers. To test this, I estimate the effect of the Head Start grant-writing assistance on mother's school enrollment separately for mothers aged 18 to 25 years, for mothers aged 26 to 33 years, and for mothers aged 33 years and older. I report the estimates in Table 6 and these estimates provide suggestive evidence that school enrollment increased for younger mothers as a result of the availability of Head Start. For example, school enrollment increased significantly by nearly 15 percentage points for mothers younger than 25 while it had a much smaller and insignificant increase for older mothers. Note that standard errors are quite large to rule out possible large effects for mothers aged 26 to 33 .

\subsection{Estimates are Robust to Whether Census Imputed Values are Dropped}

The decennial censuses imputed many variables to overcome nonresponse and to reduce disclosure risks for outliers. To examine whether the imputed values affect estimates, I re- 
estimate equations (1) and (2) after all imputed or allocated values are dropped from my sample. I compare the estimates using whole sample to those using not-imputed data in Table 7. As shown, these two sets of estimates are very close to each other, suggesting that the imputed values did not significantly affect my estimates.

\section{Conclusion}

In this paper, I exploit a discontinuity in the Office of Economic Opportunity's offer of grant-writing assistance that led to a discontinuity in Head Start spending in the late 1960s to explore differences in county-level maternal labor supply and maternal schooling. The results provide suggestive evidence that the more availability of Head Start led to an increase the nursery school enrollment of children and a decrease in maternal labor supply. There is no evidence that the availability of Head Start increased maternal employment, a different result from some previous literature on kindergarten enrollment around the similar period (Cascio 2009; Gelbach 2002). In addition, the ITT estimates imply a relatively large, negative effect of enrollment on maternal labor supply and the standard errors are quite large to rule out these large potential effects. 


\section{Bibliography}

Baker, Michael, Jonathan Gruber, and Kevin Milligan. 2008. "Universal Child Care, Maternal Labor Supply, and Family Well-Being." Journal of Political Economy 116 (4): 709-45.

Blau, David, and Janet Currie. 2006. "Pre-School, Day Care, and After-School Care: Who's Minding the Kids?" Handbook of the Economics of Education 2: 1163-1278.

Cameron, A. Colin, and Douglas L. Miller. 2015. "A Practitioner's Guide to Cluster-Robust Inference." Journal of Human Resources 50 (2): 317-72.

Cascio, Elizabeth U. 2009. "Maternal Labor Supply and the Introduction of Kindergartens into American Public Schools." Journal of Human Resources 44 (1): 140-170. doi:http://jhr.uwpress.org/archive/.

Fitzpatrick, Maria Donovan. 2010. "Preschoolers Enrolled and Mothers at Work? The Effects of Universal Prekindergarten." Journal of Labor Economics 28 (1) (January 1): 51-85.

Gelbach, Jonah B. 2002. "Public Schooling for Young Children and Maternal Labor Supply." The American Economic Review 92 (1) (March 1): 307-322.

Gelman, Andrew, and Guido Imbens. 2014. "Why High-Order Polynomials Should Not Be Used in Regression Discontinuity Designs." NBER Working Paper 20405. National Bureau of Economic Research, Inc. https://ideas.repec.org/p/nbr/nberwo/20405.html.

Havnes, Tarjei, and Magne Mogstad. 2011. "Money for Nothing? Universal Child Care and Maternal Employment." Journal of Public Economics 95 (11-12): 1455-65. doi:http://www.elsevier.com/locate/inca/505578/.

Hsueh, JoAnn, and Mary Farrell. 2012. "Enhanced Early Head Start with Employment Services: 42-Month Impacts from the Kansas and Missouri Sites of the Enhanced Services for the Hard-to-Employ Demonstration and Evaluation Project.” OPRE Report 2012-05.

Lee, David S., and Thomas Lemieux. 2010. "Regression Discontinuity Designs in Economics." Journal of Economic Literature 48 (2): 281-355. doi:10.1257/jel.48.2.281.

Long, Cuiping. 2015. "Experimental Evidence of the Effect of Head Start on Mothers' Human Capital Investment.” Working Paper.

Ludwig, Jens, and Douglas L. Miller. 2005. "Does Head Start Improve Children's Life Chances? Evidence from a Regression Discontinuity Design.” Working Paper 11702. National Bureau of Economic Research. http://www.nber.org/papers/w11702.

Ludwig, Jens, and Douglas L. Miller. 2007. "Does Head Start Improve Children's Life Chances? Evidence from a Regression Discontinuity Design." The Quarterly Journal of Economics 122 (1) (February 1): 159-208. doi:10.1162/qjec.122.1.159.

National Center for Education Statistics. "Digest of Education Statistics, 2014." Accessed October 29, 2015. https://nces.ed.gov/programs/digest/d14/tables/dt14_202.10.asp. 
Office of Child Development, U. S. Department of Health, Education, and Welfare. Project Head Start Statistical Fact Sheet: Fiscal Year 1970.

Sabol, Terri J., and P. Lindsay Chase-Lansdale. 2015. "The Influence of Low-Income Children's Participation in Head Start on Their Parents' Education and Employment." Journal of Policy Analysis and Management 34 (1): 136-61. doi:10.1002/pam.21799.

Vinovskis, Maris A. 2005. The Birth of Head Start : Preschool Education Policies in the Kennedy and Johnson Administrations /. Chicago : University of Chicago Press, 88. 
Figure 1.

Head Start Funding per Four-year Old in 1968

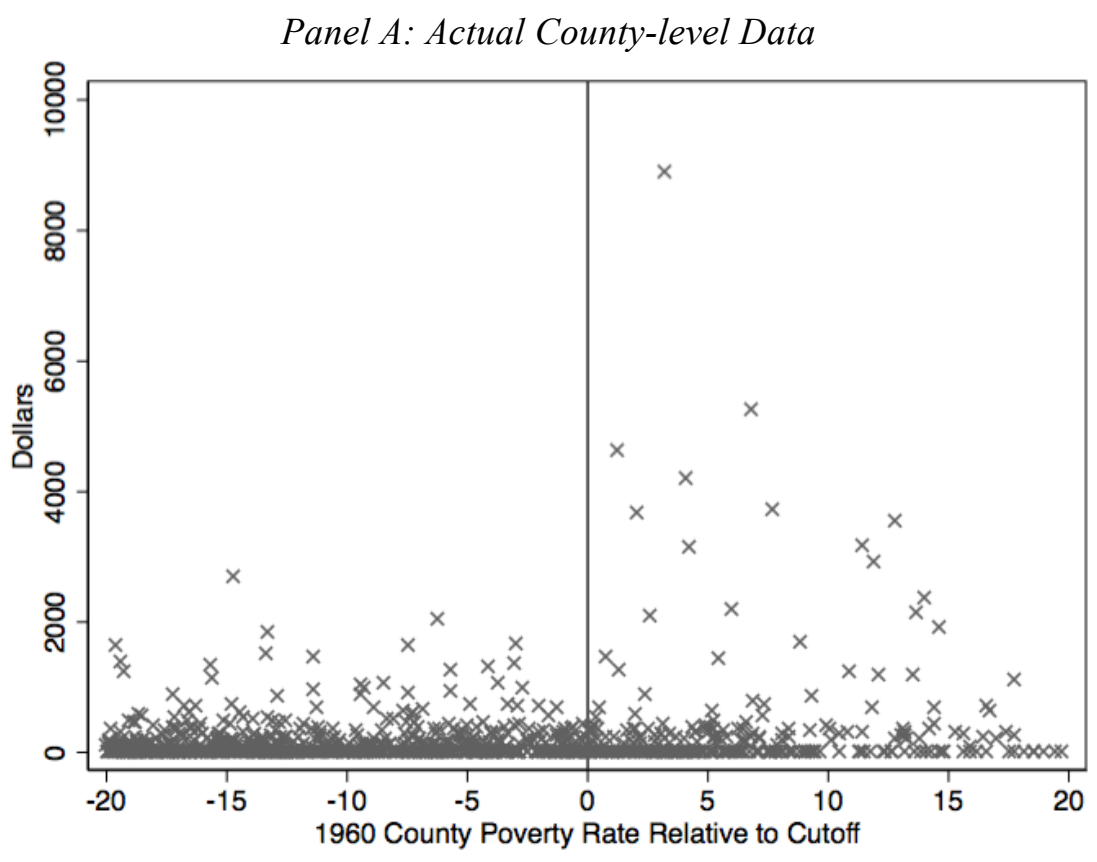

Panel B: Binned and Regression Fitted Data

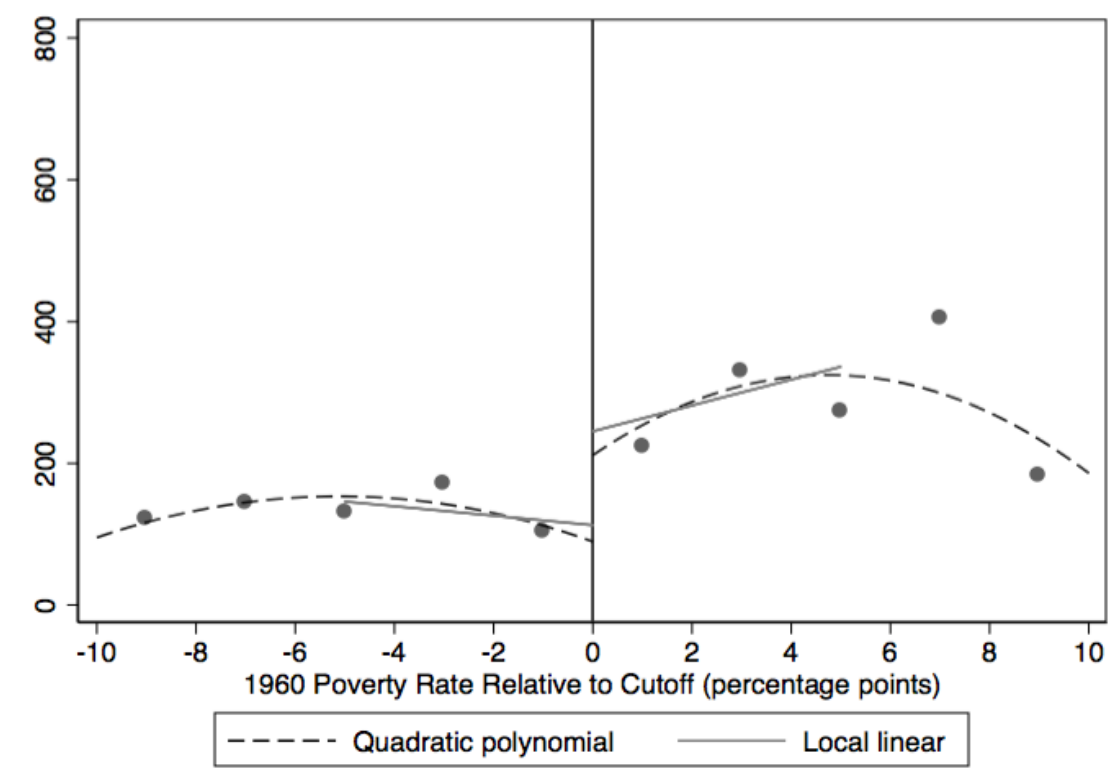


Figure 2.

Head Start Funding per Four-year Old in 1972

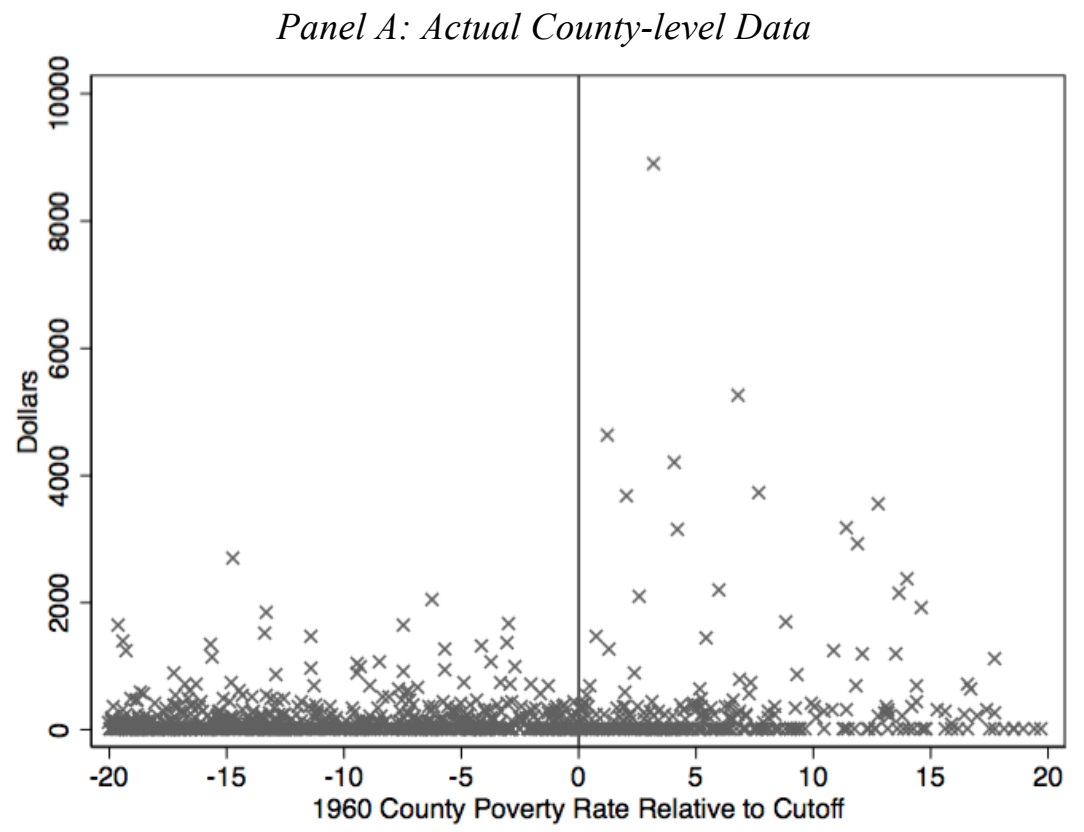

Panel B: Binned and Regression Fitted Data

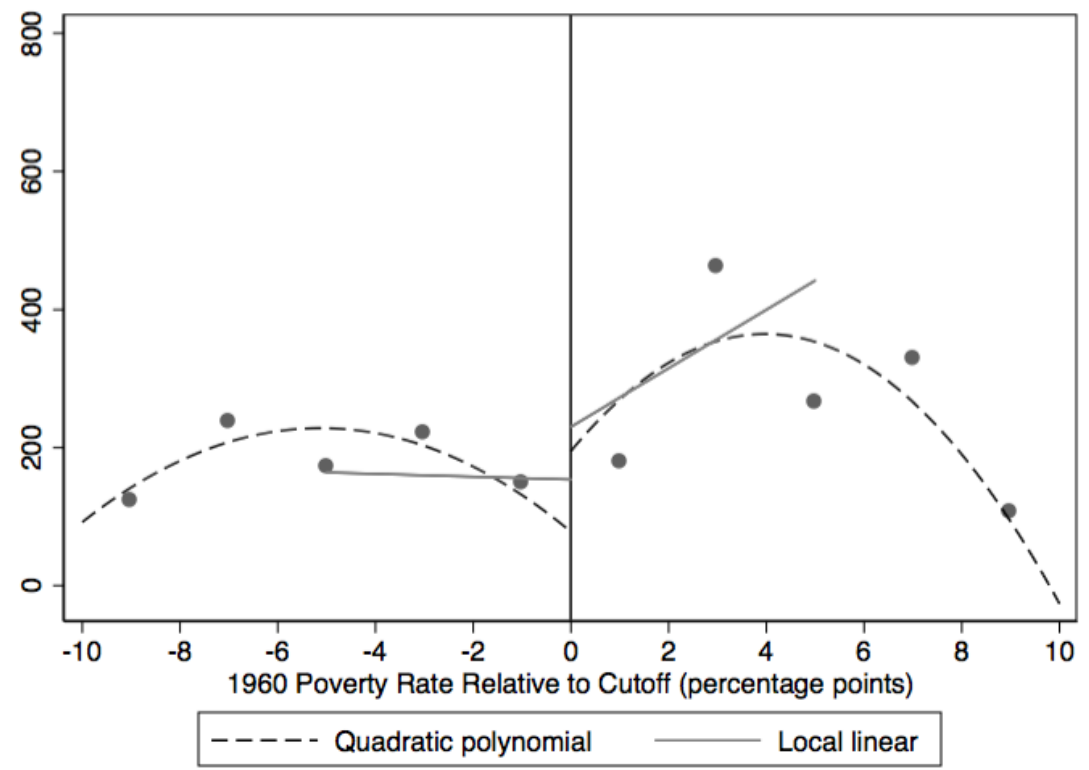


Figure 3.

Fraction of Three and Four years old Enrolled in Nursery School in 1970

Panel A: All

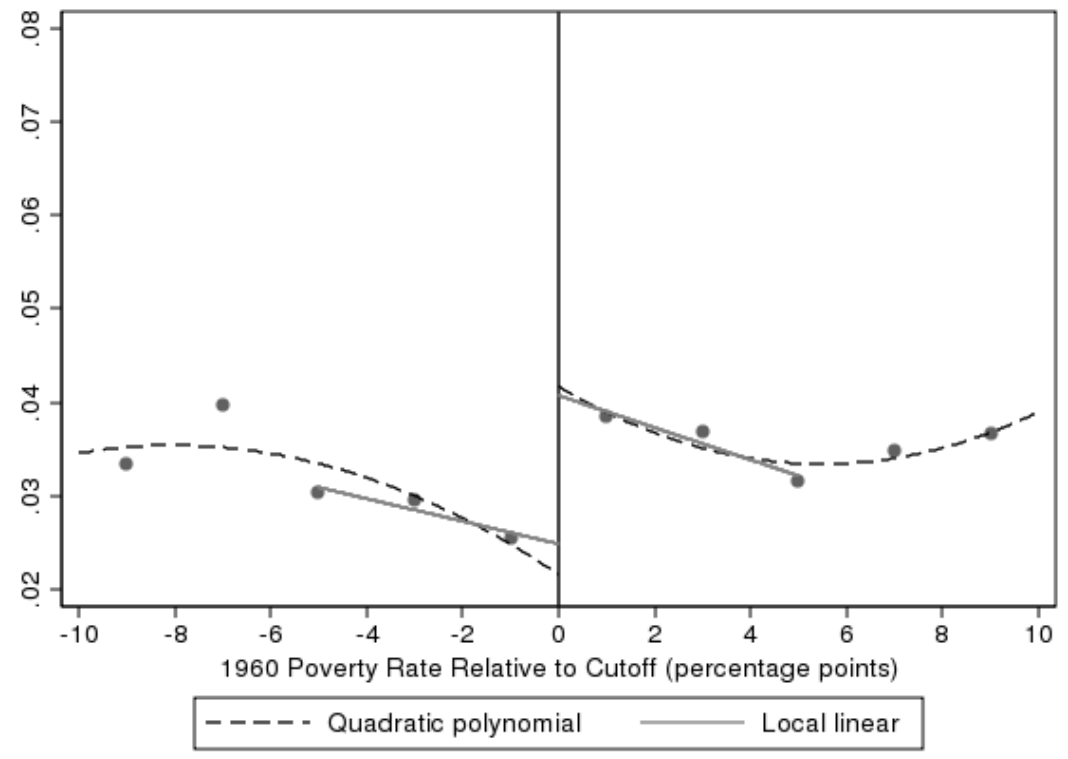

Panel B: Families with Income below County Median

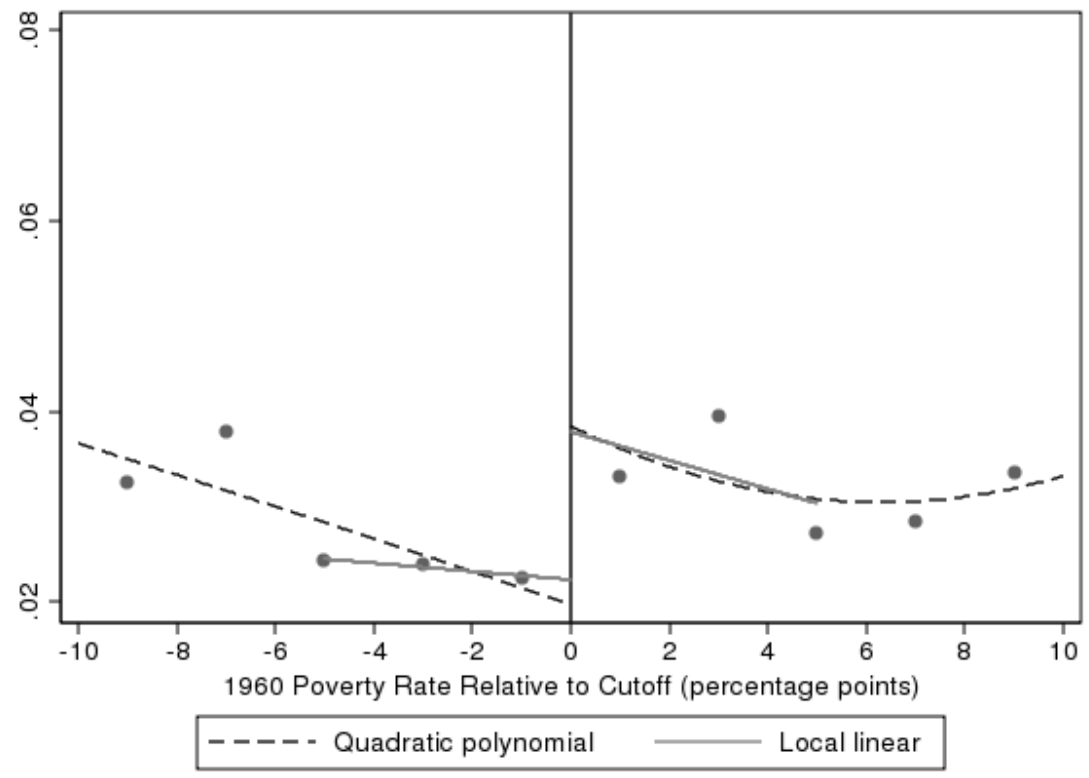


Figure 4.

Number of Counties and Households by 1960 Poverty Rate

Panel A: Number of Counties

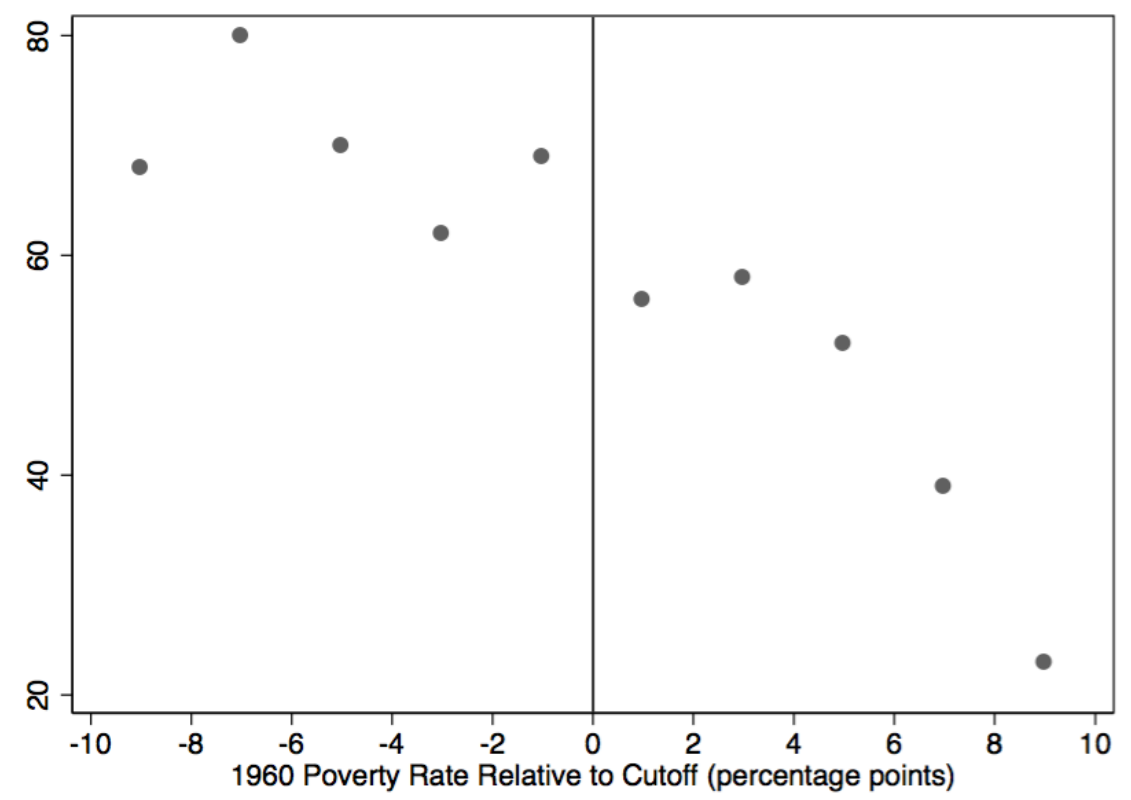

Panel B: Number of Households

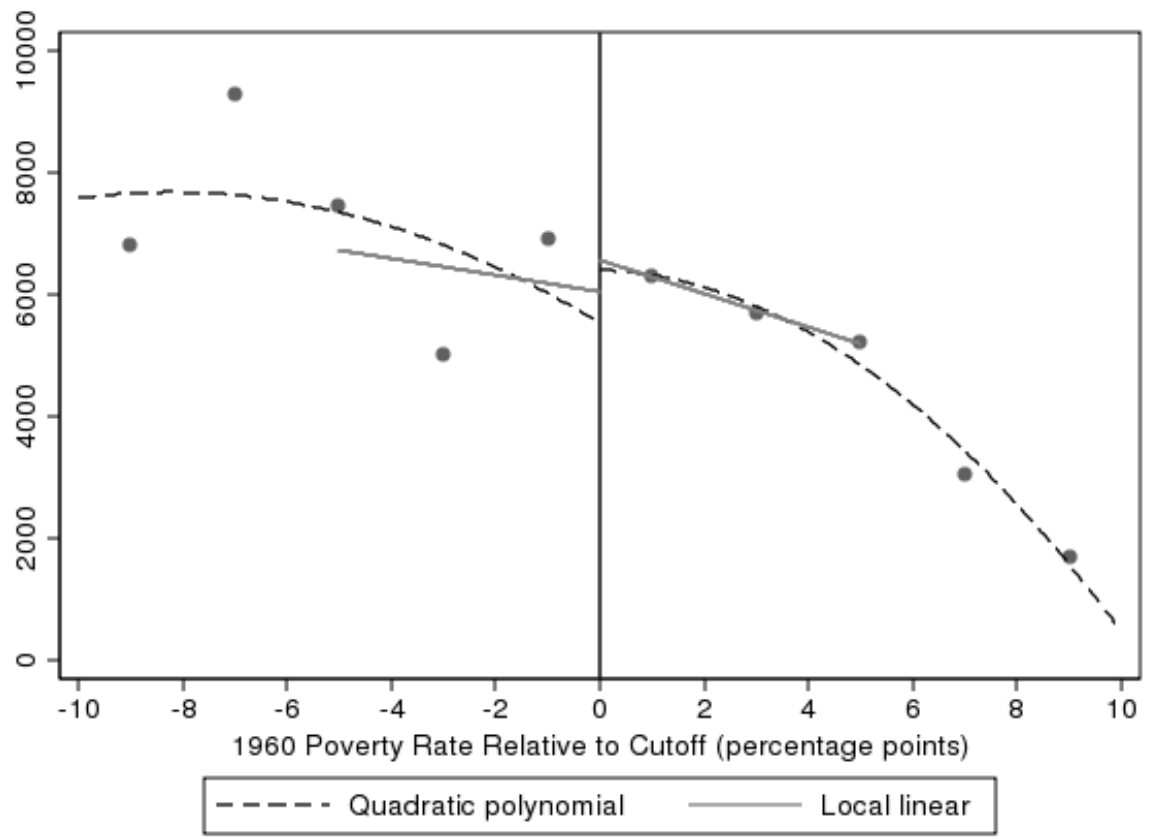


Figure 5.

Maternal Outcomes

Panel A: Fraction Currently Employed

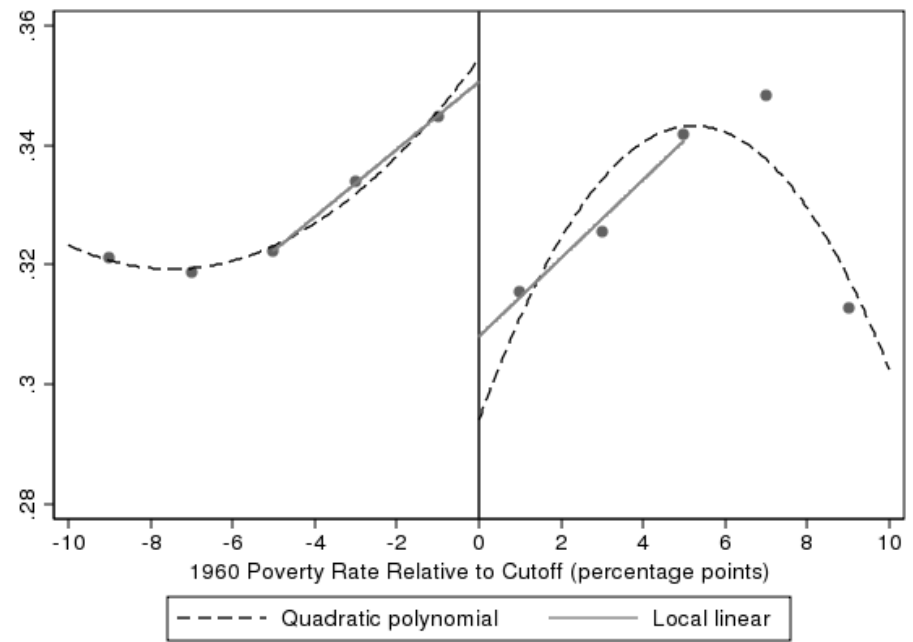

Panel C: Fraction Worked Last Year

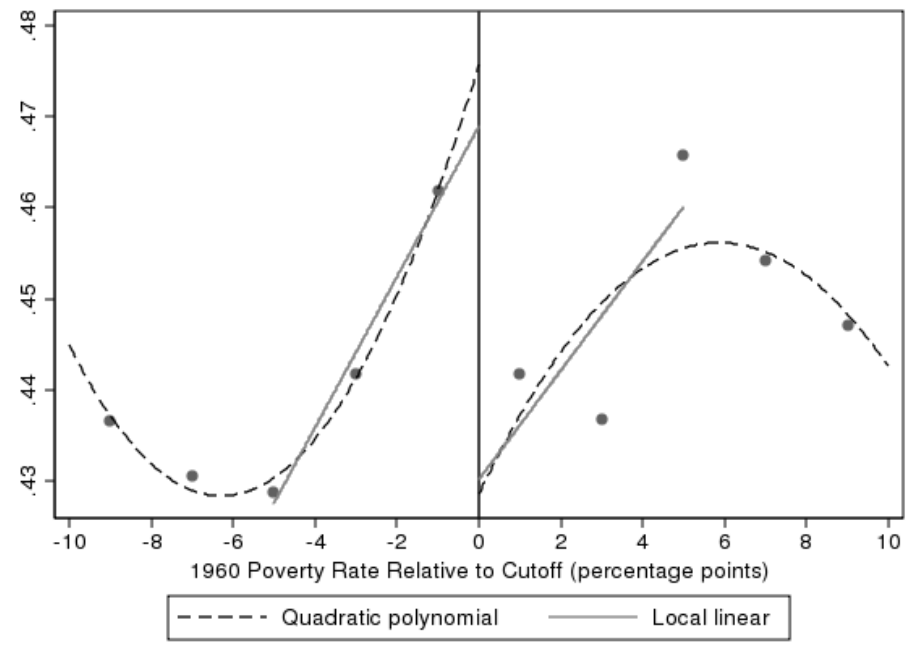

Panel B: Hours of Work

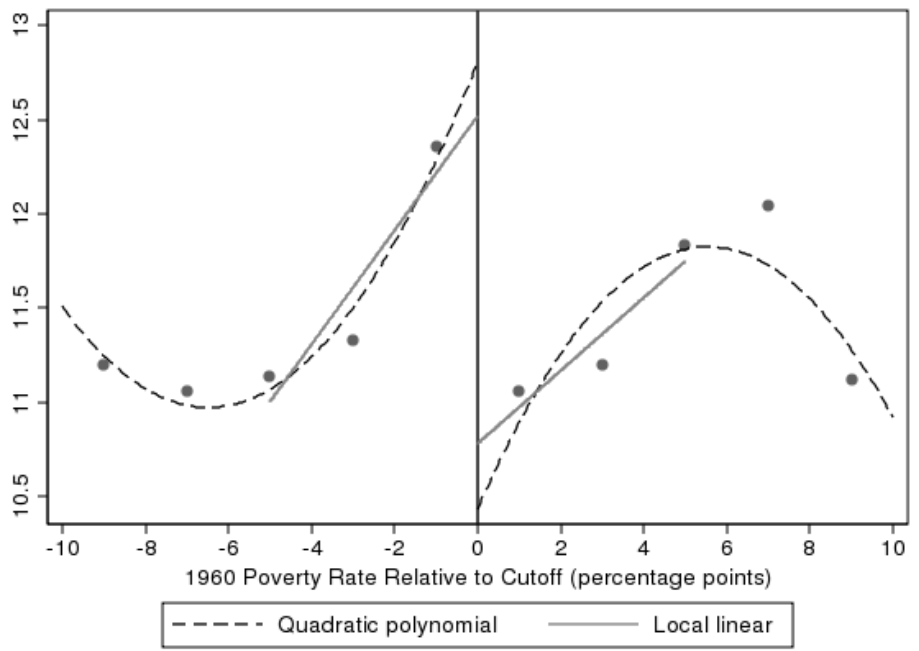

Panel D: Number of Weeks Worked Last Year

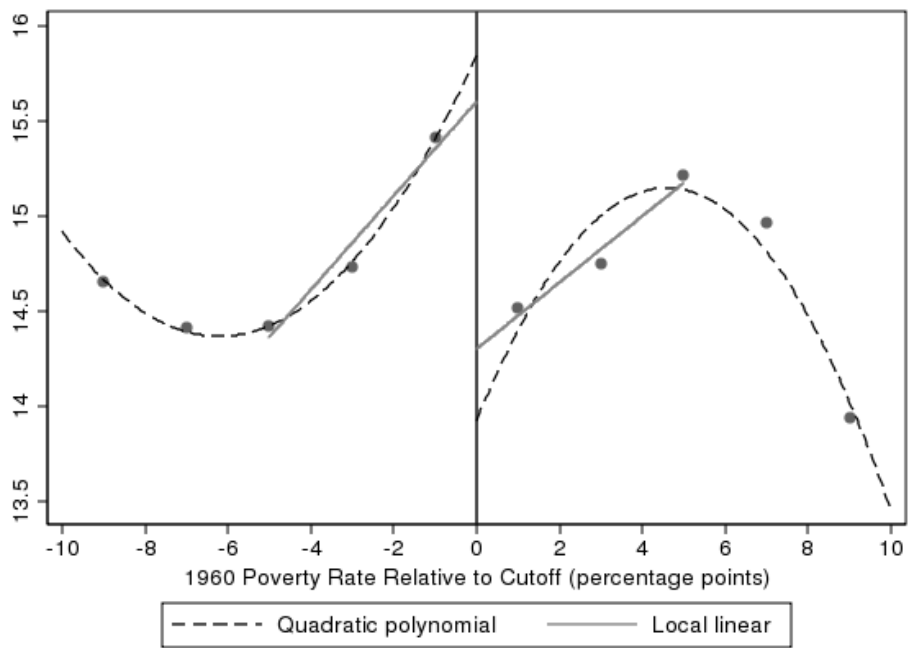


Figure 5. cont.

Maternal Outcomes

Panel E: Earnings (in dollars)

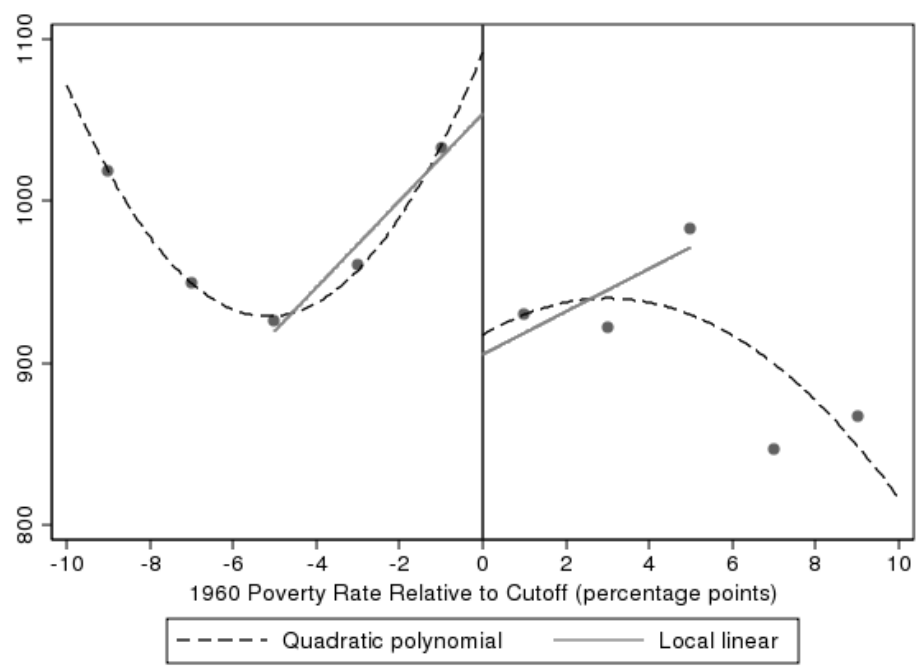

Panel G: Fraction Enrolled in School

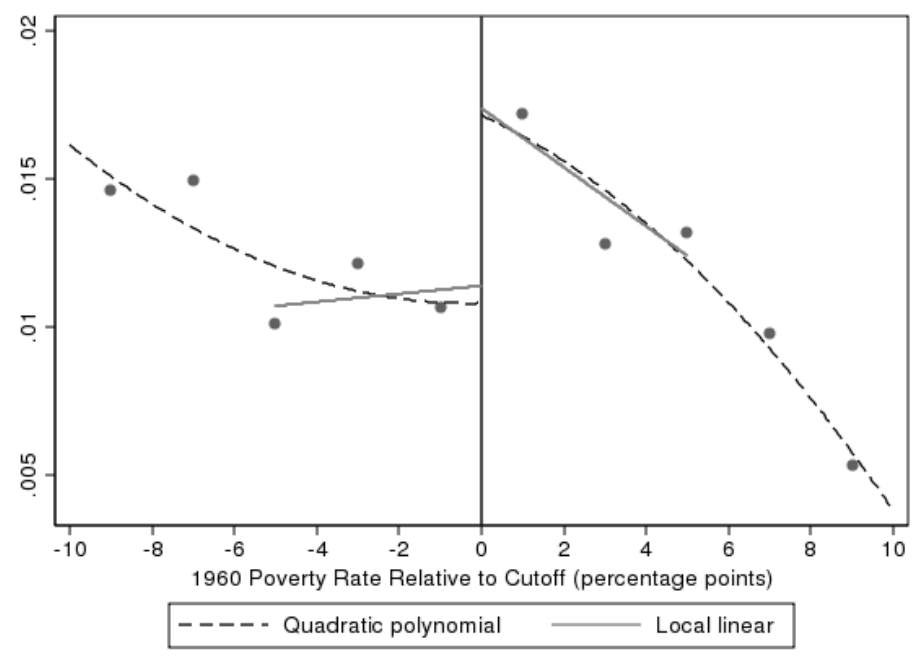

Panel F: Fraction Receiving Public Assistance

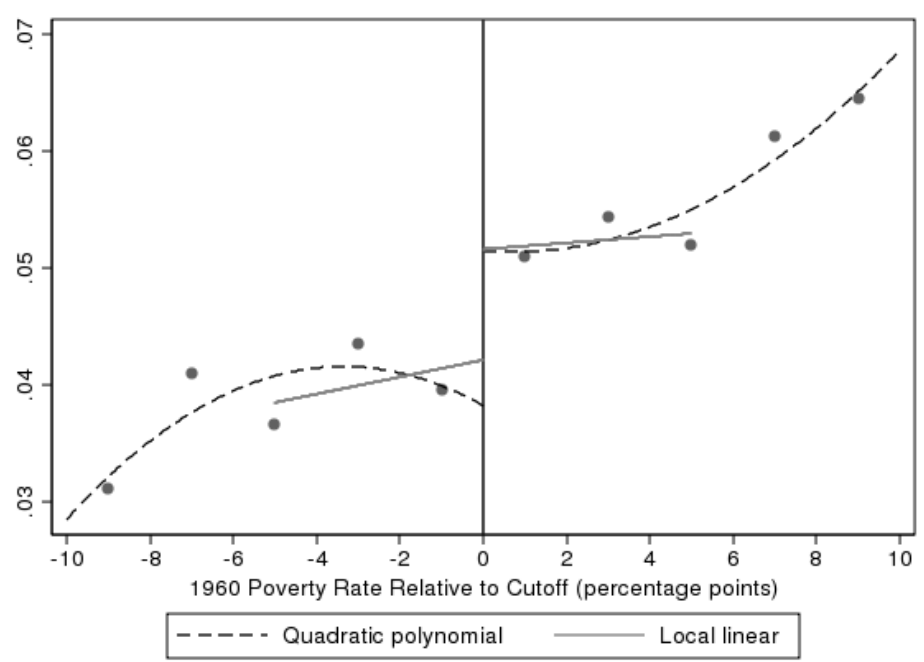


Table 1.

Estimates of the Effect of the Grant-writing Assistance on

Head Start Funding and Nursery school Enrollment

\begin{tabular}{|c|c|c|c|c|c|}
\hline & \multirow{2}{*}{$\begin{array}{l}\text { Control } \\
\text { Mean }\end{array}$} & \multicolumn{2}{|c|}{ Quadratic Polynomial } & \multicolumn{2}{|c|}{ Local Linear } \\
\hline & & {$[-10,10]$} & {$[-5,5]$} & {$[-10,10]$} & {$[-5,5]$} \\
\hline 1968 Head Start funding per child & 130 & $\begin{array}{c}121.939 \\
(107.513)\end{array}$ & $\begin{array}{c}101.169 \\
(143.550)\end{array}$ & $\begin{array}{c}149.599 \\
(100.668)\end{array}$ & $\begin{array}{c}132.707 \\
(110.200)\end{array}$ \\
\hline 1972 Head Start funding per child & 159 & $\begin{array}{c}116.934 \\
(105.428)\end{array}$ & $\begin{array}{c}77.733 \\
(150.696)\end{array}$ & $\begin{array}{l}167.949 * \\
(97.950)\end{array}$ & $\begin{array}{c}76.378 \\
(103.963)\end{array}$ \\
\hline 1970 Nursery School Enrollment & 0.028 & $\begin{array}{c}0.025 * * \\
(0.011)\end{array}$ & $\begin{array}{c}0.025 * * \\
(0.012)\end{array}$ & $\begin{array}{c}0.014 \\
(0.009)\end{array}$ & $\begin{array}{l}0.020^{*} \\
(0.010)\end{array}$ \\
\hline $\begin{array}{l}1970 \text { Nursery School Enrollment for } \\
\text { Children from families with below } \\
\text { Median Income }\end{array}$ & 0.025 & $\begin{array}{l}0.023 * \\
(0.012)\end{array}$ & $\begin{array}{c}0.017 \\
(0.013)\end{array}$ & $\begin{array}{c}0.020 * * \\
(0.010)\end{array}$ & $\begin{array}{c}0.020 * * \\
(0.010)\end{array}$ \\
\hline 1968 other social funding per capita & 210 & $\begin{array}{l}40.337 * \\
(24.458)\end{array}$ & $\begin{array}{c}14.172 \\
(38.947)\end{array}$ & $\begin{array}{l}43.915^{*} \\
(26.448)\end{array}$ & $\begin{array}{c}43.214 \\
(26.941)\end{array}$ \\
\hline 1972 other social funding per capita & 449 & $\begin{array}{c}-4.217 \\
(31.218)\end{array}$ & $\begin{array}{c}28.966 \\
(39.016)\end{array}$ & $\begin{array}{r}11.375 \\
(21.608)\end{array}$ & $\begin{array}{c}7.826 \\
(29.666)\end{array}$ \\
\hline $\begin{array}{l}\text { Number of Counties } \\
\text { Fraction Counties with Positive } \\
\text { Spending }\end{array}$ & & $38 \%$ & $35 \%$ & $38 \%$ & $35 \%$ \\
\hline
\end{tabular}

Notes: Unit of observation is a county. Control means are the means for counties with 1960 poverty rates within five percentage points below the poverty cutoff. $[-10,10]$ means that the data range 10 percentage points to the left of the poverty cutoff and 10 percentage points to the right of the poverty cutoff are used. Similarly for $[-5,5]$. Cluster-bootstrap (500 times) standard errors (clustered by state) are reported in parentheses. Each cell is from a separate regression. Regressions do not include covariates or state fixed effects. * Significant at 10 percent level; ** Significant at 5 percent level; *** Significant at 1 percent level 
Table 2.

Estimates of the Effect of the Grant-writing Assistance on Pre-policy Measures in 1960

\begin{tabular}{|c|c|c|c|c|c|}
\hline & \multirow[b]{2}{*}{$\begin{array}{c}\text { Control } \\
\text { Mean }\end{array}$} & \multicolumn{2}{|c|}{ Quadratic Polynomial } & \multicolumn{2}{|c|}{ Local Linear } \\
\hline & & {$[-10,10]$} & {$[-5,5]$} & {$[-10,10]$} & {$[-5,5]$} \\
\hline $\begin{array}{l}\text { LFP for Women with } \\
\qquad \text { Children under } 6\end{array}$ & 0.254 & $\begin{array}{l}-0.033 \\
(0.026)\end{array}$ & $\begin{array}{l}-0.035 \\
(0.031)\end{array}$ & $\begin{array}{c}0.002 \\
(0.024)\end{array}$ & $\begin{array}{l}-0.022 \\
(0.026)\end{array}$ \\
\hline $\begin{array}{l}\text { LFP for Married Women } \\
\text { with Children Under } 6\end{array}$ & 0.223 & $\begin{array}{l}-0.007 \\
(0.017)\end{array}$ & $\begin{array}{l}-0.002 \\
(0.028)\end{array}$ & $\begin{array}{c}0.009 \\
(0.017)\end{array}$ & $\begin{array}{l}-0.006 \\
(0.018)\end{array}$ \\
\hline County Unemployment Rate & 0.059 & $\begin{array}{c}0.005 \\
(0.005)\end{array}$ & $\begin{array}{l}0.012^{*} \\
(0.007)\end{array}$ & $\begin{array}{c}0.001 \\
(0.005)\end{array}$ & $\begin{array}{c}0.003 \\
(0.005)\end{array}$ \\
\hline Median Family Income & 2590.83 & $\begin{array}{c}72.986 \\
(63.258)\end{array}$ & $\begin{array}{l}-13.369 \\
(68.816)\end{array}$ & $\begin{array}{c}69.702 \\
(48.942)\end{array}$ & $\begin{array}{c}51.452 \\
(60.099)\end{array}$ \\
\hline $\begin{array}{l}\text { Median Years of School for } \\
\text { Ages } 25 \text { and Over }\end{array}$ & 8.095 & $\begin{array}{c}0.005 \\
(0.231)\end{array}$ & $\begin{array}{c}0.238 \\
(0.347)\end{array}$ & $\begin{array}{l}-0.027 \\
(0.157)\end{array}$ & $\begin{array}{l}-0.014 \\
(0.190)\end{array}$ \\
\hline $\begin{array}{l}\text { Enrolled in School for } \\
\qquad \text { Ages } 25 \text { to } 34\end{array}$ & 0.040 & $\begin{array}{l}-0.002 \\
(0.010)\end{array}$ & $\begin{array}{l}-0.010 \\
(0.012)\end{array}$ & $\begin{array}{c}0.008 \\
(0.008)\end{array}$ & $\begin{array}{c}0.004 \\
(0.009)\end{array}$ \\
\hline Number of Counties & & 575 & 311 & 575 & 311 \\
\hline
\end{tabular}

Notes: Unit of observation is a county and data are from 1960 census tabulations. Control means are the means for counties with 1960 poverty rates within five percentage points below the poverty cutoff. Cluster-bootstrap (500 times) standard errors are reported in parentheses. $[-10,10]$ means that data range 10 percentage points to the left of the poverty cutoff and 10 percentage points to the right of the poverty cutoff are used. Similarly for $[-5,5]$.

* Significant at 10 percent level; ** Significant at 5 percent level; *** Significant at 1 percent level 
Table 3.

P-values on the Treatment Indicator when Covariates are Dependent Variables

\begin{tabular}{lcccc}
\hline \hline & \multicolumn{2}{c}{ Quadratic Polynomial } & \multicolumn{2}{c}{ Local Linear } \\
\cline { 2 - 5 } & {$[-10,10]$} & {$[-5,5]$} & {$[-10,10]$} & {$[-5,5]$} \\
\hline Fraction Single & $0.079^{*}$ & $0.059^{*}$ & $0.086^{*}$ & $0.031^{* *}$ \\
Number of Children & $0.002^{* * *}$ & $0.091^{*}$ & $0.010^{* *}$ & $0.001^{* * *}$ \\
Years of Schooling & 0.252 & $0.099^{*}$ & 0.407 & 0.221 \\
Fraction White & 0.610 & 0.926 & 0.404 & 0.227 \\
Fraction Black & 0.633 & 0.387 & 0.868 & 0.720 \\
Average Age (mothers, in years) & 0.109 & 0.577 & 0.276 & 0.282 \\
Fraction aged 18-24 & $0.027^{* *}$ & $0.053^{*}$ & 0.181 & $0.012^{* *}$ \\
Fraction aged 25-34 & $0.026^{* *}$ & 0.195 & 0.566 & $0.033^{* *}$ \\
Fraction aged 35-54 & 0.618 & 0.989 & 0.421 & 0.437 \\
Fraction aged 55 and older & 0.143 & 0.717 & 0.136 & 0.110 \\
Fraction Urban Residence & 0.116 & $0.068^{*}$ & 0.575 & 0.522 \\
Population size & 0.714 & 0.573 & 0.186 & 0.521 \\
& & & & \\
Chi-Squared Test from & 0.115 & $0.021^{* *}$ & 0.192 & 0.107 \\
Seemingly Unrelated Regressions & & & & \\
Number of Counties in sample & 575 & 311 & 575 & 311 \\
\hline
\end{tabular}

Notes: Unit of observation is a county and data are from 1970 decennial censuses. Values in cells are p-values for the significance of the treatment indicator variable from regressions when the listed county characteristics are used as dependent variables. Clusterbootstrap (500 times) standard errors are reported in parentheses. 
Table 4.

Estimates of the Effect of Head Start Grant-writing Assistance on Maternal Labor Supply and Schooling

\begin{tabular}{|c|c|c|c|c|c|}
\hline & \multirow[b]{2}{*}{$\begin{array}{c}\text { Control } \\
\text { Mean }\end{array}$} & \multicolumn{2}{|c|}{ Quadratic Polynomial } & \multicolumn{2}{|c|}{ Local Linear } \\
\hline & & $\begin{array}{c}(1) \\
{[-10,10]}\end{array}$ & $\begin{array}{c}(2) \\
{[-10,10]}\end{array}$ & $\begin{array}{c}(3) \\
{[-5,5]}\end{array}$ & $\begin{array}{c}(4) \\
{[-5,5]}\end{array}$ \\
\hline Covariates Included (Y/N) & & $\mathbf{N}$ & $\mathbf{Y}$ & $\mathbf{N}$ & $\mathbf{Y}$ \\
\hline Currently Employed & 0.334 & $\begin{array}{l}-0.050^{*} \\
(0.027)\end{array}$ & $\begin{array}{l}-0.032 \\
(0.021)\end{array}$ & $\begin{array}{c}-0.046^{* *} \\
(0.023)\end{array}$ & $\begin{array}{l}-0.025 \\
(0.017)\end{array}$ \\
\hline Hours of Work & 11.621 & $\begin{array}{c}-1.806^{*} \\
(0.991)\end{array}$ & $\begin{array}{l}-1.130 \\
(0.755)\end{array}$ & $\begin{array}{c}-1.793 * * \\
(0.906)\end{array}$ & $\begin{array}{l}-0.901 \\
(0.649)\end{array}$ \\
\hline Worked Last Year & 0.446 & $\begin{array}{l}-0.043 \\
(0.031)\end{array}$ & $\begin{array}{l}-0.021 \\
(0.027)\end{array}$ & $\begin{array}{l}-0.041 \\
(0.031)\end{array}$ & $\begin{array}{l}-0.020 \\
(0.027)\end{array}$ \\
\hline Weeks Worked Last Year & 14.838 & $\begin{array}{l}-1.414 \\
(1.192)\end{array}$ & $\begin{array}{l}-0.646 \\
(1.010)\end{array}$ & $\begin{array}{l}-1.528 \\
(1.175)\end{array}$ & $\begin{array}{l}-0.752 \\
(0.887)\end{array}$ \\
\hline Earnings & 972.2 & $\begin{array}{r}-135.525 \\
(83.866)\end{array}$ & $\begin{array}{l}-91.900 \\
(69.024)\end{array}$ & $\begin{array}{c}-171.715^{* *} \\
(81.086)\end{array}$ & $\begin{array}{c}-127.620^{* *} \\
(59.277)\end{array}$ \\
\hline Receive Public Assistance & 0.042 & $\begin{array}{c}0.013 * * \\
(0.006)\end{array}$ & $\begin{array}{c}0.002 \\
(0.006)\end{array}$ & $\begin{array}{l}0.013^{*} \\
(0.008)\end{array}$ & $\begin{array}{l}-0.003 \\
(0.007)\end{array}$ \\
\hline Enrolled in School & 0.011 & $\begin{array}{c}0.005 \\
(0.005)\end{array}$ & $\begin{array}{c}0.002 \\
(0.005)\end{array}$ & $\begin{array}{c}0.006 \\
(0.004)\end{array}$ & $\begin{array}{c}0.002 \\
(0.004)\end{array}$ \\
\hline Number of Counties & & 575 & 575 & 311 & 311 \\
\hline
\end{tabular}

Notes: Unit of observation is a county and data are from 1970 decennial censuses. Covariates include all those listed in Table 3 and are included as quadratic terms. Control means are the means for counties with 1960 poverty rates within five percentage points below the poverty cutoff. Clusterbootstrap (500 times) standard errors are reported in parentheses. Regressions do not include state fixed effects.

* Significant at 10 percent level; ** Significant at 5 percent level; *** Significant at 1 percent level 
Table 5.

Estimates of the Effect of Head Start Grant-writing Assistance on Maternal Labor Supply and Schooling by Presence of Younger Children

\begin{tabular}{|c|c|c|c|c|}
\hline & \multicolumn{2}{|c|}{ Has Younger Children } & \multicolumn{2}{|c|}{ No Younger Children } \\
\hline & $\begin{array}{c}\text { Control } \\
\text { Mean }\end{array}$ & {$[-10,10]$} & $\begin{array}{c}\text { Control } \\
\text { Mean } \\
\end{array}$ & {$[-10,10]$} \\
\hline Children in Nursery School & 0.022 & $\begin{array}{c}0.018 \\
(0.011)\end{array}$ & 0.032 & $\begin{array}{l}0.024^{*} \\
(0.013)\end{array}$ \\
\hline Currently Employed & 0.245 & $\begin{array}{l}-0.029 \\
(0.026)\end{array}$ & 0.387 & $\begin{array}{c}-0.053^{*} \\
(0.030)\end{array}$ \\
\hline Hours of Work & 8.375 & $\begin{array}{l}-0.995 \\
(1.095)\end{array}$ & 13.664 & $\begin{array}{c}-1.967^{*} \\
(1.093)\end{array}$ \\
\hline Worked Last Year & 0.368 & $\begin{array}{l}-0.031 \\
(0.035)\end{array}$ & 0.486 & $\begin{array}{l}-0.051 \\
(0.035)\end{array}$ \\
\hline Weeks Worked Last Year & 10.444 & $\begin{array}{l}-0.521 \\
(1.269)\end{array}$ & 17.440 & $\begin{array}{l}-1.771 \\
(1.301)\end{array}$ \\
\hline Earnings & 683.730 & $\begin{array}{r}-108.048 \\
(75.011)\end{array}$ & 1153.798 & $\begin{array}{c}-136.831 \\
(100.647)\end{array}$ \\
\hline Receive Public Assistance & 0.048 & $\begin{array}{c}0.025^{* *} \\
(0.011)\end{array}$ & 0.037 & $\begin{array}{c}0.005 \\
(0.008)\end{array}$ \\
\hline Enrolled in School & 0.010 & $\begin{array}{l}-0.006 \\
(0.005)\end{array}$ & 0.012 & $\begin{array}{c}0.010 \\
(0.006)\end{array}$ \\
\hline Number of Counties & & 561 & & 561 \\
\hline
\end{tabular}

Notes: Unit of observation is a county and data are from 1970 decennial censuses. Cluster-bootstrap standard errors (500 times) are reported in parentheses. Values in cells are obtained from quadratic polynomial regressions. Regressions do not include covariates or state fixed effects.

* Significant at 10 percent level; ** Significant at 5 percent level; *** Significant at 1 percent level 
Table 6.

Estimates of the Effect of the Head Start Grant-writing Assistance on Mothers' School Enrollment by Age

\begin{tabular}{cccccc}
\hline \hline & \multicolumn{3}{c}{ Quadratic Polynomial } & \multicolumn{2}{c}{ Local Linear } \\
\cline { 2 - 6 } & $\begin{array}{c}\text { Control } \\
\text { Mean }\end{array}$ & {$[-10,10]$} & {$[-5,5]$} & {$[-10,10]$} & {$[-5,5]$} \\
\hline \multirow{2}{*}{ Ages 18-25 } & 0.011 & $0.013^{* *}$ & $0.015^{*}$ & $0.015^{* * *}$ & $0.015^{* *}$ \\
& & $(0.006)$ & $(0.009)$ & $(0.005)$ & $(0.006)$ \\
Sample Size & & 555 & 300 & 555 & 300 \\
Ages 26-33 & & & & 0.007 & 0.005 \\
& 0.012 & 0.004 & 0.005 & $(0.005)$ & $(0.006)$ \\
Sample Size & & $(0.007)$ & $(0.010)$ & 566 & 305 \\
Ages 33 and Older & 0.011 & -0.008 & -0.008 & 0.001 & -0.003 \\
& & $(0.006)$ & $(0.008)$ & $(0.004)$ & $(0.005)$ \\
Sample Size & & 566 & 294 & 551 & 294 \\
\hline
\end{tabular}

Notes: Unit of observation is a county and data are from 1970 decennial censuses. Clusterbootstrap standard errors (500 times) are reported in parentheses. Regressions do not include covariates or state fixed effects.

* Significant at 10 percent level; ** Significant at 5 percent level; *** Significant at 1 percent level 
Table 7. Not-imputed Data

Estimates of the Effect of Head Start Grant-writing Assistance on Maternal Outcomes

\begin{tabular}{|c|c|c|c|c|c|}
\hline & & \multicolumn{2}{|c|}{ Quadratic Polynomial } & \multicolumn{2}{|c|}{ Local Linear } \\
\hline & & $\begin{array}{l}\text { Whole } \\
\text { sample }\end{array}$ & Not-imputed & $\begin{array}{l}\text { Whole } \\
\text { sample }\end{array}$ & Not-imputed \\
\hline & $\begin{array}{c}\text { Not-imputed } \\
\text { Mean }\end{array}$ & {$[-10,10]$} & {$[-10,10]$} & {$[-5,5]$} & {$[-5,5]$} \\
\hline Employed & 0.316 & $\begin{array}{l}-0.050^{*} \\
(0.027)\end{array}$ & $\begin{array}{l}-0.047 \\
(0.031)\end{array}$ & $\begin{array}{l}-0.046^{* *} \\
(0.023)\end{array}$ & $\begin{array}{l}-0.046^{*} \\
(0.025)\end{array}$ \\
\hline Hours of Work & 10.984 & $\begin{array}{r}-1.806^{*} \\
(0.991)\end{array}$ & $\begin{array}{l}-1.883 \\
(1.214)\end{array}$ & $\begin{array}{c}-1.793 * * \\
(0.906)\end{array}$ & $\begin{array}{l}-1.946^{*} \\
(1.025)\end{array}$ \\
\hline Worked Last Year & 0.426 & $\begin{array}{l}-0.043 \\
(0.031)\end{array}$ & $\begin{array}{l}-0.041 \\
(0.034)\end{array}$ & $\begin{array}{l}-0.041 \\
(0.031)\end{array}$ & $\begin{array}{l}-0.039 \\
(0.032)\end{array}$ \\
\hline Weeks Worked Last Year & 14.090 & $\begin{array}{l}-1.414 \\
(1.192)\end{array}$ & $\begin{array}{l}-1.297 \\
(1.269)\end{array}$ & $\begin{array}{c}-1.528 \\
(1.175)\end{array}$ & $\begin{array}{l}-1.363 \\
(1.208)\end{array}$ \\
\hline Earnings & 920.198 & $\begin{array}{r}-135.525 \\
(83.866)\end{array}$ & $\begin{array}{l}-108.886 \\
(96.914)\end{array}$ & $\begin{array}{c}-171.715^{* * *} \\
(81.086)\end{array}$ & $\begin{array}{l}-145.471 \\
(89.534)\end{array}$ \\
\hline Receive Public Assistance & 0.042 & $\begin{array}{l}0.013 * * \\
(0.006)\end{array}$ & $\begin{array}{c}0.013^{* *} \\
(0.006)\end{array}$ & $\begin{array}{c}0.013^{*} \\
(0.008)\end{array}$ & $\begin{array}{l}0.016^{*} \\
(0.008)\end{array}$ \\
\hline Enrolled in School & 0.006 & $\begin{array}{c}0.005 \\
(0.005)\end{array}$ & $\begin{array}{c}0.002 \\
(0.003)\end{array}$ & $\begin{array}{c}0.006 \\
(0.004)\end{array}$ & $\begin{array}{c}0.003 \\
(0.003)\end{array}$ \\
\hline Number of Counties & & 575 & 575 & 311 & 311 \\
\hline
\end{tabular}

Notes: Unit of observation is a county and data are from 1970 decennial censuses. Not-imputed sample is limited to mothers without allocated values in the outcomes list in table. Cluster-bootstrap standard errors (500 times) are reported in parentheses. Regressions do not include covariates or state fixed effects.

* Significant at 10 percent level; ** Significant at 5 percent level; *** Significant at 1 percent level 
Figure A1. 1960 County Characteristics

Labor Force Participation (LFP) for Women with Children under 6

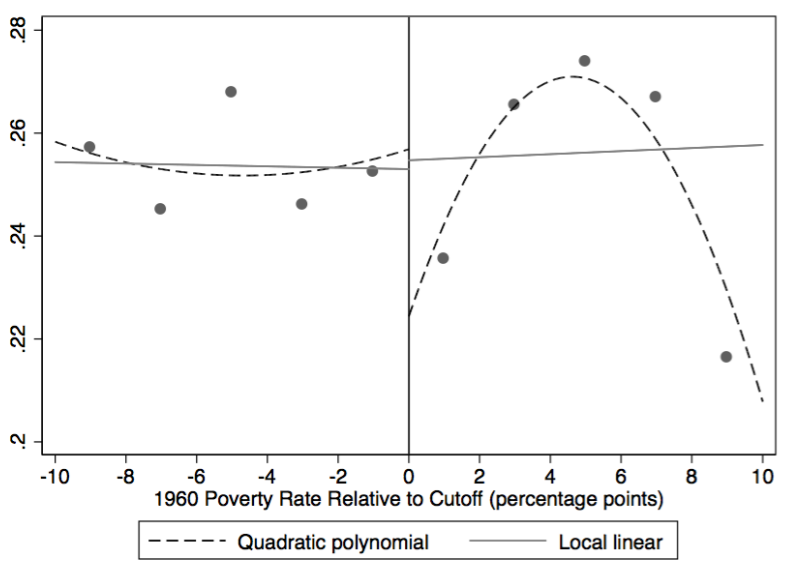

Median Family Income

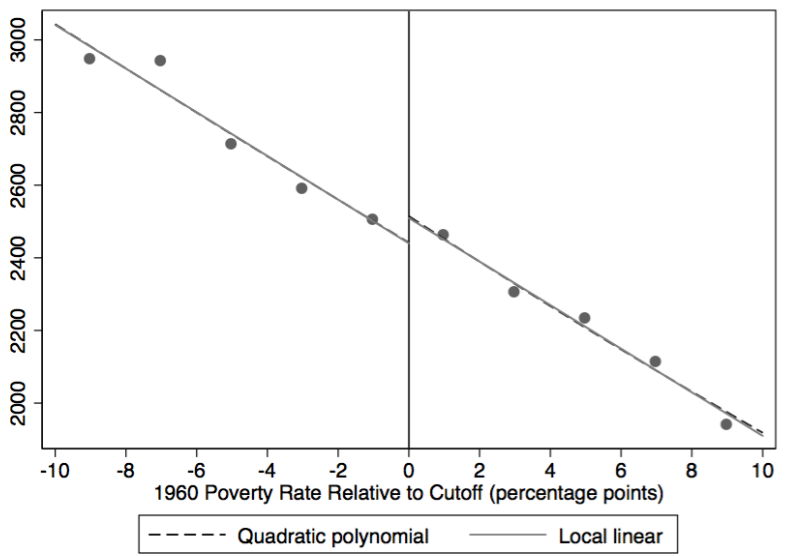

Median Years of School for Ages 25 and Over

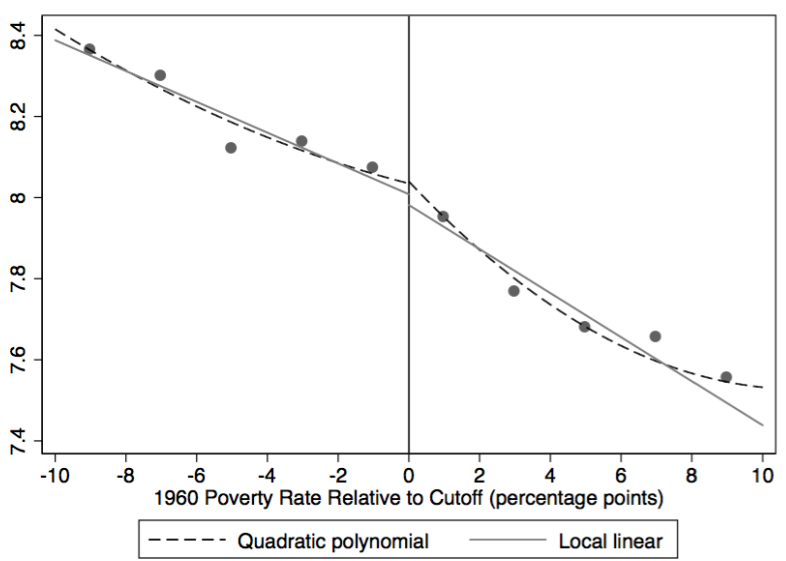

LFP for Married Women with Children under 6

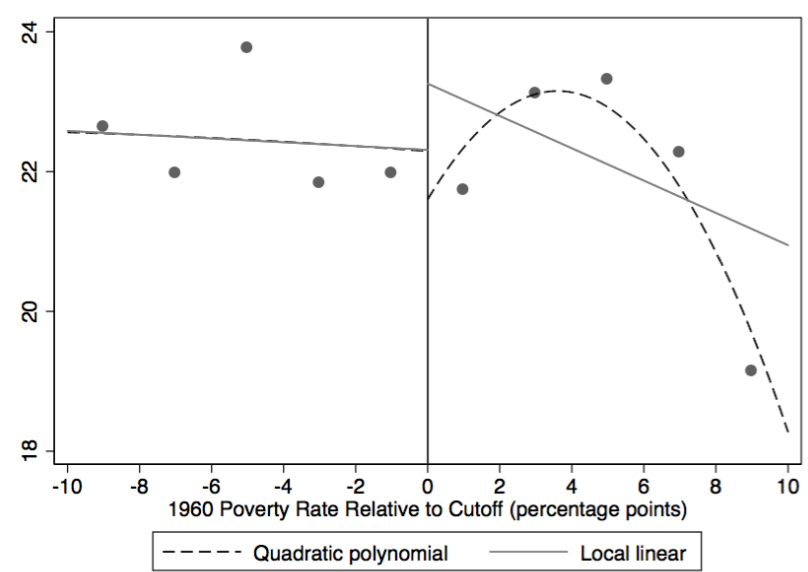

Unemployment Rate for Civilian Labor Force

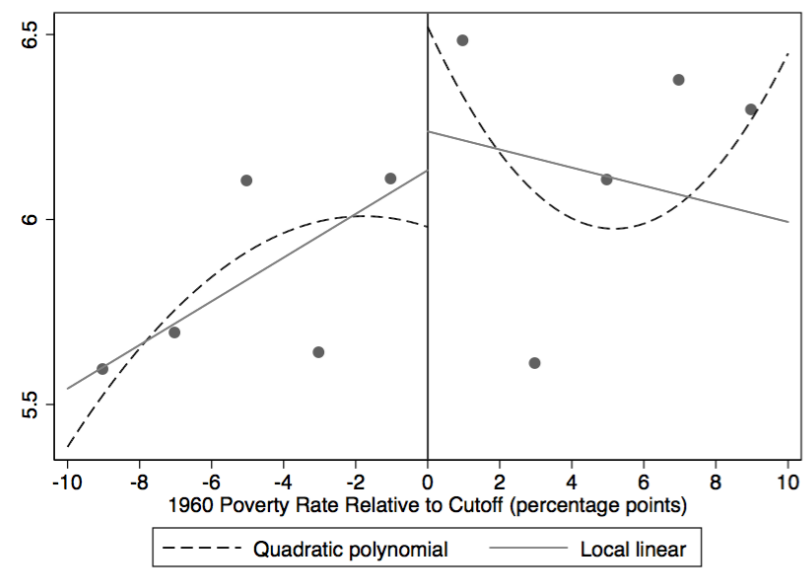

Fraction Ages 25-34 Enrolled in School

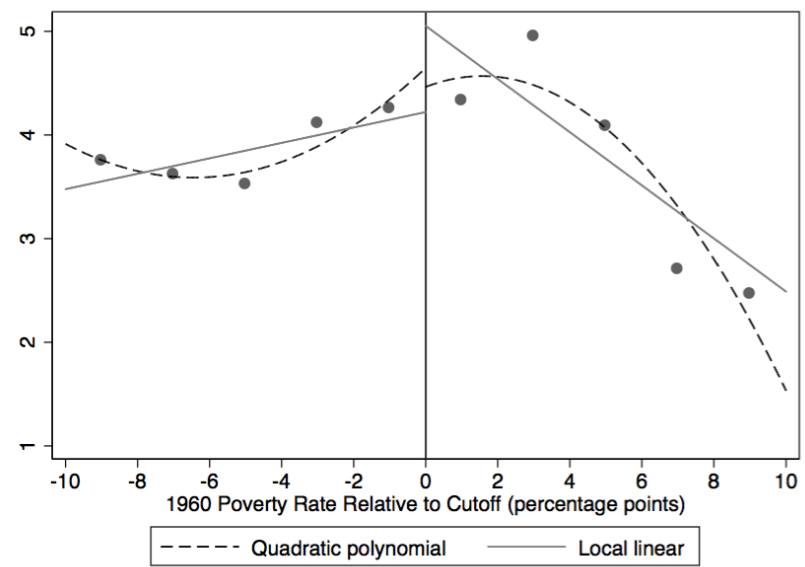


A1.

Specification Test : P-values from Wald Tests of the Joint Significance of Bin Dummy Variables

\begin{tabular}{|c|c|c|c|c|c|c|c|}
\hline & \multicolumn{7}{|c|}{ Poverty Range } \\
\hline & {$[-36,36]$} & {$[-30,30]$} & {$[-25,25]$} & {$[-20,20]$} & {$[-15,15]$} & {$[-10,10]$} & {$[-5,5]$} \\
\hline \multicolumn{8}{|l|}{ Local Linear } \\
\hline Employed & 0.000 & 0.000 & 0.000 & 0.000 & 0.092 & 0.191 & 0.678 \\
\hline Hours of Work & 0.000 & 0.000 & 0.000 & 0.000 & 0.000 & 0.130 & 0.714 \\
\hline Worked Last Year & 0.000 & 0.000 & 0.000 & 0.002 & 0.061 & 0.884 & 0.939 \\
\hline Weeks Worked Last Year & 0.000 & 0.000 & 0.000 & 0.045 & 0.189 & 0.807 & 0.933 \\
\hline Earnings & 0.000 & 0.000 & 0.000 & 0.012 & 0.011 & 0.042 & 0.809 \\
\hline Receive Public Assistance & 0.000 & 0.000 & 0.000 & 0.000 & 0.135 & 0.031 & 0.835 \\
\hline Enrolled in School & 0.000 & 0.000 & 0.000 & 0.000 & 0.000 & 0.246 & 0.795 \\
\hline Child in Nursery school & 0.000 & 0.000 & 0.000 & 0.000 & 0.508 & 0.402 & 0.505 \\
\hline Children in Nursery or Kindergarten & 0.000 & 0.000 & 0.000 & 0.000 & 0.000 & 0.003 & 0.562 \\
\hline Head Start Spending 1968 & 0.000 & 0.000 & 0.000 & 0.001 & 0.224 & 0.675 & 0.190 \\
\hline Head Start Spending 1972 & 0.000 & 0.000 & 0.050 & 0.000 & 0.096 & 0.277 & 0.069 \\
\hline Other Social Spending 1968 & 0.000 & 0.000 & 0.000 & 0.007 & 0.090 & 0.070 & 0.006 \\
\hline Other Social Spending 1972 & 0.000 & 0.000 & 0.055 & 0.044 & 0.380 & 0.913 & 0.801 \\
\hline \multicolumn{8}{|l|}{ Quadratic Polynomial } \\
\hline Employed & 0.000 & 0.000 & 0.011 & 0.012 & 0.196 & 0.464 & 0.853 \\
\hline Hours of Work & 0.000 & 0.000 & 0.000 & 0.001 & 0.037 & 0.680 & 0.550 \\
\hline Worked Last Year & 0.000 & 0.000 & 0.009 & 0.174 & 0.437 & 0.705 & 0.983 \\
\hline Weeks Worked Last Year & 0.000 & 0.000 & 0.002 & 0.188 & 0.629 & 0.883 & 0.929 \\
\hline Earnings & 0.000 & 0.000 & 0.000 & 0.001 & 0.061 & 0.142 & 0.901 \\
\hline Receive Public Assistance & 0.000 & 0.000 & 0.000 & 0.000 & 0.116 & 0.276 & 0.775 \\
\hline Enrolled in School & 0.000 & 0.000 & 0.000 & 0.000 & 0.000 & 0.582 & 0.737 \\
\hline Child in Nursery school & 0.000 & 0.000 & 0.001 & 0.027 & 0.770 & 0.674 & 0.486 \\
\hline Children in Nursery or Kindergarten & 0.000 & 0.000 & 0.000 & 0.000 & 0.000 & 0.003 & 0.328 \\
\hline Head Start Spending 1968 & 0.000 & 0.000 & 0.000 & 0.000 & 0.388 & 0.551 & 0.766 \\
\hline Head Start Spending 1972 & 0.000 & 0.000 & 0.001 & 0.000 & 0.245 & 0.153 & 0.130 \\
\hline Other Social Spending 1968 & 0.000 & 0.000 & 0.001 & 0.066 & 0.132 & 0.053 & 0.391 \\
\hline Other Social Spending 1972 & 0.000 & 0.000 & 0.376 & 0.162 & 0.677 & 0.850 & 0.725 \\
\hline Number of counties in sample & 2157 & 1710 & 1363 & 1064 & 812 & 575 & 311 \\
\hline
\end{tabular}

Notes: Unit of observation is a county and data are from 1970 decennial census. All regressions include bin dummy variables as additional regressors. This table reports the p-values from a Wald test of the joint significance of bin dummy variables. Cluster-bootstrap standard errors are used. 
A2.

Fraction of Three- and Four-year Olds' School Enrollment by Poverty Range and Year

Panel A. Nursery School Enrollment

ational

3096

$0.109 \quad 0.063$

0.280

0.118

Counties with Poverty rate $<39.1984$

2026

$0.116 \quad 0.061$

$0.294 \quad 0.115$

Counties with Poverty Rate between 39.1984 and 59.1984

$\begin{array}{lllll}774 & 0.043 & 0.034 & 0.185 & 0.096\end{array}$

Counties with Poverty Rate $\geq 59.1984$

296

$0.040 \quad 0.041$

0.160 0.076 